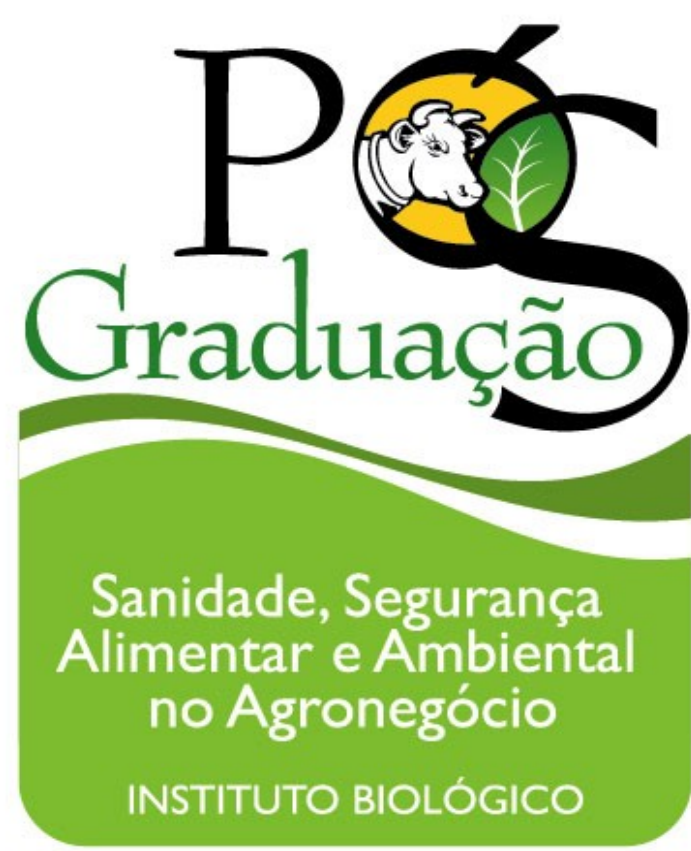

\title{
AVALIAÇÃO DO EFEITO DO pH DO SOLO \\ E IRRIGAÇÃOO NA INCIDÊNCIA E SEVERIDADE \\ DA SARNA DA BATATA CAUSADA POR STREPTOMYCES SPP.
}

\section{HARIELLY MARIANNE COSTA MARQUES}

Dissertação apresentada ao Instituto Biológico, da Agência Paulista de Tecnologia dos Agronegócios, para obtenção do título de Mestre em Sanidade, Segurança Alimentar e Ambiental no Agronegócio.

Área de Concentração: Sanidade Vegetal Orientador: Dra. Suzete A. Lanza Destéfano

São Paulo

2019 
Secretaria de Agricultura e Abastecimento do Estado de São Paulo

Agência Paulista de Tecnologia dos Agronegócios

\section{Instituto Biológico}

Programa de Pós-Graduação em Sanidade, Segurança Alimentar e Ambiental no Agronegócio

Avaliação do efeito do pH do solo e irrigação na incidência e severidade da sarna da batata causada por Streptomyces spp.

Harielly Marianne Costa Marques

Dissertação apresentada para obtenção do título de Mestre em Sanidade, Segurança Alimentar e Ambiental no Agronegócio.

Área de Concentração: Segurança

Alimentar e Sanidade no Agroecossistema 


\section{Harielly Marianne Costa Marques}

Avaliação do efeito do pH do solo e irrigação na incidência e severidade da sarna da batata causada por Streptomyces spp.

Dissertação apresentada para obtenção do título de Mestre em Sanidade, Segurança Alimentar e Ambiental no Agronegócio.

Área de Concentração: Segurança Alimentar e Sanidade no Agroecossistema

Orientadora: Prof ${ }^{\mathrm{a}}$. Dra. Suzete Aparecida Lanza Destéfano 
Eu Harielly Marianne Costa Marques, autorizo o Instituto Biológico (IB-APTA), da Secretaria de Agricultura e Abastecimento do Estado de São Paulo, a disponibilizar gratuitamente e sem ressarcimento dos direitos autorias, o presente trabalho acadêmico de minha autoria, no portal, biblioteca digital, catálogo eletrônico ou qualquer outra plataforma eletrônica do IB para fins de leitura, estudo, pesquisa e/ou impressão pela Internet desde que citada a fonte.

Assinatura:

Data

Dados Internacionais de Catalogação na Publicação (CIP) Secretaria de Agricultura e Abastecimento do Estado de São Paulo Núcleo de Informação e Documentação - IB

\footnotetext{
Marques, Harielly Marianne Costa.

Avaliação do efeito do $\mathrm{pH}$ do solo e irrigação na incidência e severidade da sarna da batata causada por Streptomyces spp. / Harielly Marianne Costa Marques. - São Paulo, 2019.

$54 \mathrm{p}$.

doi: 10.31368/PGSSAAA.2019D.HM004

Dissertação (Mestrado). Instituto Biológico (Sāo Paulo). Programa de PósGraduação.

Área de concentração: Segurança Alimentar e Sanidade no Agroecossistema. Linha de pesquisa: Biodiversidade: caracterização, interaçōes, interaçōes ecológicas em agroecossistemas.
}

Orientador: Suzete Aparecida Lanza Destéfano.

Versão do título para o inglês: Evaluation of $\mathrm{pH}$ soil effect and irrigation on the incidence and severity of potato scab caused by Streptomyces spp.

1. Sarna da batata 2. Manejo 3. Potencial hidrogeniônico 4. Umidade do solo Marques, Harielly Marianne Costa II. Destéfano, Suzete Aparecida Lanza III. Instituto Biológico (São Paulo) IV. Título.

IB/Bibl./2019/004 


\section{SECRETARIA DE AGRICULTURA E \\ ABASTECIMENTO \\ AGÊNCIA PAULISTA DE TECNOLOGIA DOS \\ AGRONEGÓCIOS \\ INSTITUTO BIOLÓGICO}

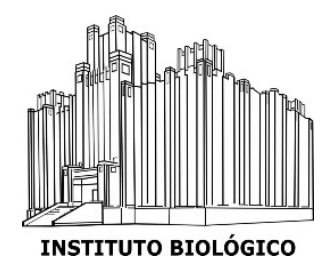

Pós-Graduação

Av. Cons. Rodrigues Alves 1252

CEP 04014-002 - São Paulo - SP

secretariapg@biologico.sp.gov.br

\section{FOLHA DE APROVAÇÃO}

Nome do candidato: Harielly Marianne Costa Marques

Título: Mestrado

Orientador: Dra. Suzete Aparecida Lanza Destéfano

Dissertação apresentada ao Instituto Biológico da Agência Paulista de Tecnologia dos Agronegócios para obtenção do título de Mestre em Sanidade, Segurança Alimentar e Ambiental no Agronegócio.

Área de Concentração: Sanidade Vegetal

Aprovada em:

Banca Examinadora

Prof. Dr.: S

Instituição:

Julgamento:

Assinatura:

Prof. Dr.:

Instituição:

Julgamento:

Assinatura:

Prof. Dr.:

Instituição:

Julgamento:

Assinatura: 
Aos meus pais, Helder e Cristiane por sempre me incentivarem na busca dos meus sonhos.

Ao meu esposo, Vinícius luz da minha vida. 


\section{AGRADECIMENTOS}

À Deus primeiramente, por ser minha força e proteção. Ele é o motivo de tudo em minha vida, sem ele nada sou.

À Dra. Suzete Aparecida Lanza Destéfano por acreditar no meu trabalho e não medir esforços para que esse trabalho fosse realizado. Obrigada por sua amizade e torcida.

À Fundação Coordenação de Aperfeiçoamento de Pessoal de Nível Superior (CAPES), pela concessão da bolsa de Mestrado. O presente trabalho foi realizado com apoio da Coordenação de Aperfeiçoamento de Pessoal Nível Superior - Brasil (CAPES) - Código de Financiamento 001.

À empresa Carolina Soil por ter gentilmente nos cedido os substratos já com os valores de $\mathrm{pH}$ corrigidos.

À empresa Solei Papa Brasil pela disponibilização dos tubérculos de batata para todos os experimentos realizados.

Aos membros da banca de qualificação Dr. Thiago Leandro Factor e Dra. Adriana Parada Dias da Silveira pelas contribuições com esse trabalho. Em especial ao Dr. Thiago pela paciência para me ensinar os testes estatísticos.

Aos meus colegas de laboratório Dra. Mariana Ferreira Tonin, MSc. Mariana Perreira Appy e MSc. Alex Augusto Tomaseto, pelos ensinamentos práticos de laboratório, não teria conseguido sem a ajuda de vocês.

Às amigas que o mestrado me presenteou Erika, Nathi, Mari e Maripy, que levarei para vida. Erika, com um coração imenso e caridoso e Nathi a colombiana mais brasileira que conheço, minhas "migas" de todas as horas, diminuindo minha solidão, obrigada por me aceitarem bem do jeito que eu sou e aceitarem viverem todos os momentos de loucura juntas. Mari obrigada por todos os ensinamentos, e por ter sido meu apoio nos momentos de crise, você é minha inspiração como profissional. Maripy, minha companheira diária, sem você a carga teria sido bem mais pesada, tudo que sei de Streptomyces é graças a você.

Ao meu esposo Vinícius, por nenhum segundo se quer, ter me deixado desanimar. Por ter comprado esse sonho junto comigo e não ter medido esforços para que ele fosse realizado. Obrigada por ser esse companheiro, amigo e marido maravilhoso, por aceitar dividir sua vida e construir uma nova família comigo! Amo você!

Aos meus pais Helder e Cristiane por serem os melhores pais que eu poderia ter, obrigada por terem "plantado a semente" do estudo na minha vida, por não terem 
desistido de me fazerem uma pessoa melhor e por lutarem durante toda a minha vida para a realização dos meus sonhos. Aos meus irmãos Helder Júnior e Cristiny por torcerem e vibrarem com as minhas vitórias e pela parceria que jamais será rompida. Obrigada por serem eternamente a minha família, amo vocês! 
MARQUES, Harielly Mariannne Costa. Avaliação do efeito do pH do solo e irrigação na incidência e severidade da sarna da batata causada por Streptomyces spp. 2019.

54 f. Dissertação (Mestrado em Sanidade, Segurança Alimentar e Ambiental no Agronegócio) - Instituto Biológico, Agência Paulista de Tecnologia dos Agronegócios, Secretaria de Agricultura e Abastecimento do Estado de São Paulo, São Paulo 2019.

\section{RESUMO}

A sarna da batata, causada por diferentes espécies do gênero Streptomyces spp., é considerada uma das doenças mais importantes da bataticultura do ponto de vista econômico. Até o momento, não há uma forma eficiente de controle da doença e por isso linhas de pesquisas diversificadas estão sendo seguidas buscando-se uma forma de combater o fitopatógeno. Algumas estratégias de manejo têm sido investigadas incluindo a aplicação de produtos químicos, biológicos e utilização de variedades de batata resistentes, porém ainda não há relatos concretos do impacto do $\mathrm{pH}$ e dos regimes de irrigação sobre a doença. Desse modo, o presente trabalho teve como objetivo avaliar o efeito do $\mathrm{pH}$ do solo e de regimes de irrigação na incidência e severidade da sarna da batata causada por diferentes espécies Streptomyces spp. Os testes de substratos com valores de PH de 4,0; 4,5; 5,5; 6,5 e 7,5 foram conduzidos em casa de vegetação. Foram testados também três regimes de irrigação: 1 vez na semana, em dias alternados e diariamente. As espécies testadas foram S. scabiei, S. acidiscabies, Streptomyces sp., S. caviscabies e S. europaeiscabiei. O delineamento experimental para o teste do $\mathrm{pH}$ foi o de blocos casualizados disposto em esquema fatorial 5 (pHs) x 2 (com e sem o patógeno), com 5 repetições e para o teste de regime de irrigação, esquema fatorial 3 (irrigação) x 2 (com e sem o patógeno). Os resultados para o pH do substrato mostraram diferenças significativas entre os tratamentos onde os valores de $\mathrm{pH}$ mais ácidos de 4,0 e 4,5 apresentaram menor incidência e severidade da doença na maioria das espécies testadas. Nos diferentes regimes de irrigação não foram observadas diferenças significativas entre os tratamentos. A acidificação do solo é considerada uma estratégia clássica de manejo da doença, assim os resultados obtidos no presente estudo contribuem para corroborar essa hipotése.

Palavras chave: Sarna da batata, Manejo, Potencial hidrogeniônico e Umidade do solo. 
MARQUES, Harielly Mariannne Costa. Evaluation of pH soil effect and irrigation on the incidence and severity of potato scab caused by Streptomyces spp. 2019. $54 \mathrm{f}$. Dissertação (Mestrado em Sanidade, Segurança Alimentar e Ambiental no Agronegócio) - Instituto Biológico, Agência Paulista de Tecnologia dos Agronegócios, Secretaria de Agricultura e Abastecimento do Estado de São Paulo, São Paulo 2019.

\begin{abstract}
Potato scab caused by different species of phytopathogenic Streptomyces is considered one of the main bacterial disease of economic importance. Until now, there is no efficient way to control the disease and due this several studies are being carried out in order to control this pathogen. Some management strategies have been investigated including application of chemical and biological products and potato cultivars resistant utilization but there are still no concrete reports of $\mathrm{pH}$ and irrigation regimes impact on the disease. The present study aimed to evaluate the effects of soil $\mathrm{pH}$ and irrigation regimes on the incidence and severity of potato scab caused by different Streptomyces species. The tests of substrates with $\mathrm{pH}$ values of $4.0 ; 4.5 ; 5.0 ; 5.5 ; 6.5$ and 7.5 were conducted in greenhouse. Three irrigation regimes were also tested: once in a week, alternated days and daily. The Streptomyces species tested were S. scabiei, S. acidiscabies, Streptomyces sp., S. caviscabies and S. europaeiscabiei. The experimental design for the $\mathrm{pH}$ test was the randomized blocks arranged in a $5 \times 2$ factorial scheme, with 5 replications and the irrigation regimes $3 \times 2$ factorial scheme. The results of $\mathrm{pH}$ tests showed significant differences between the treatments and the acid $\mathrm{pH}$ ranging 4,0 - 4,5 presented a lower incidence and severity of the disease for the most species tested. There were no significant differences observed between the treatments in relation to the irrigation regimes. The soil acidification is considered a classic strategy for management of the disease and the results obtained herein corroborated this hypothesis.
\end{abstract}

Keywords: Potato scab, Management, Potential of Hydrogen, Soil Moisture 


\section{LISTA DE FIGURAS}

Figura 1. Ciclo da sarna da batata..

Figura 2. Testes de $\mathrm{pH}$ in vitro.

Figura 3. Plantas aos 45 dias de plantio mantidas na casa de vegetação.

Figura 4. Escala diagramática para avaliação de percentual de área do tubérculo coberta pelas lesões de sarna.

Figura 5. Teste de crescimento bacteriano in vitro com a linhagem de S. acidiscabieis (IBSBF $2110^{\mathrm{T}}$ ) aos 14 dias em diferentes valores de $\mathrm{pH}$

Figura 6. Teste de crescimento bacteriano in vitro com a linhagem de S. caviscabies $\left(\right.$ IBSBF $2051^{\mathrm{T}}$ ) aos 14 dias em diferentes valores de $\mathrm{pH}$

Figura 7. Plantas aos 45 dias de crescimento. 28

Figura 8. Notas de incidência da sarna da batata em diferentes valores de $\mathrm{pH}$ dos substratos atribuídas aos sintomas causados pelas diferentes espécies de Streptomyces no período do inverno.

Figura 9. Notas de incidência da sarna da batata em diferentes $\mathrm{pH}$ dos substratos atribuídas às espécies de S. scabiei (A) e S. acidiscabies (B) nas estações de inverno e verão.

Figura 10. Tubérculos colhidos a partir dos substratos inoculados com a linhagem de $S$. acidiscabies IBSBF $2110^{\mathrm{T}}$ em diferentes valores de $\mathrm{pH}$

Figura 11. Tubérculos colhidos a partir dos substratos inoculados com a linhagem de $S$. scabiei IBSBF 2950 em diferentes valores de $\mathrm{pH}$ 34

Figura 12. Tubérculos colhidos a partir dos substratos inoculados com a linhagem de Streptomyces sp. IBSBF 2959 em diferentes valores de $\mathrm{pH}$ 


\section{LISTA DE TABELAS}

Tabela 1. Avanço dos problemas fitossanitários no Brasil, do ano de 1980 a 2012. 8

Tabela 2. Linhagens de Streptomyces spp. utilizadas no estudo 18

Tabela 3. Caracterização química dos substratos em diferentes valores de $\mathrm{pH}$.

Tabela 4. Média do halo de crescimento $(\mathrm{cm})$ de linhagens de Streptomyces spp. aos sete e 14 dias (d) após inoculação.

Tabela 5. Medidas dos $\mathrm{pH}$ dos substratos realizadas durante o desenvolvimento da planta com aferição feita pelo método de Pour Through (LEBUDE; BILDERBACK, 2009)

Tabela 6. Valores das médias das notas da incidência e severidade da sarna da batata em diferentes valores de $\mathrm{pH}$ dos substratos inoculados ou não com a linhagem de $S$. acidiscabies IBSBF $2110^{\mathrm{T}}$.

Tabela 7. Valores das médias das notas da incidência e severidade da sarna da batata em diferentes valores de $\mathrm{pH}$ dos substratos inoculados ou não com a linhagem de $S$. scabiei IBSBF 2950.

Tabela 8. Valores das médias das notas da incidência e severidade da sarna da batata em diferentes valores de $\mathrm{pH}$ dos substratos inoculados ou não com a linhagem de Streptomyces sp. IBSBF 2959.

Tabela 9. Valores das médias das notas da incidência e severidade da sarna da batata em diferentes valores de $\mathrm{pH}$ dos substratos inoculados ou não com a linhagem de $S$. caviscabies IBSBF $2051^{\mathrm{T}}$ 36

Tabela 10. Valores das médias de produtividade dos tubérculos de batata em (gramas) em diferentes valores de $\mathrm{pH}$ inoculados ou não com as linhagens de Streptomyces spp..... 38

Tabela 11. Valores das médias das notas da incidência e severidade da sarna da batata a partir de plantas cultivadas em substratos inoculados ou não com a linhagem de $S$. acidiscabies IBSBF $2110^{\mathrm{T}}$ sob diferentes regimes de irrigação.

Tabela 12. Valores das médias das notas da incidência e severidade da sarna da batata a partir de plantas cultivadas em substratos inoculados ou não com a linhagem de $S$. scabiei IBSBF 2950 sob diferentes regimes de irrigação. 
Tabela 13. Valores das médias das notas da incidência e severidade da sarna da batata a partir de plantas cultivadas em substratos inoculados ou não com a linhagem de Streptomyces sp. IBSBF 2959 sob diferentes regimes de irrigação. 42

Tabela 14. Valores das médias das notas da incidência e severidade da sarna da batata a partir de plantas cultivadas em substratos inoculados ou não com a linhagem de $S$. europaeiscabiei IBSBF $2023^{\mathrm{T}}$ sob diferentes regimes de irrigação.

Tabela 15. Valores das médias de produtividade dos tubérculos de batata em (gramas) em diferentes regimes de irrigação dos substratos com linhagens de Streptomyces spp...... 45 


\section{LISTA DE ABREVIATURAS}

$\begin{array}{ll}\text { ABBA } & \text { Associação Brasileira da Batata } \\ { }^{\circ} \mathbf{C} & \text { graus Celsius } \\ \mathbf{c m} & \text { centímetro } \\ \mathbf{c m}^{\mathbf{3}} & \text { centímetro cúbico }\end{array}$

CAPSA Centro Avançado de Pesquisa em Proteção de Plantas e Saúde Aninal

CV Coeficiente de variação

$\boldsymbol{\mu} \mathbf{L} \quad$ microlitro

FAO Food and Agriculture Organization of the United Nations

g gramas

$\mathbf{H}^{+} \quad$ hidrogênio

ha hectare

HCL ácido clorídrico

IBGE Instituto Brasileiro de Geografia e Estatística

IBSBF Coleção de Culturas de Fitobactérias do Instituto Biológico

$\begin{array}{ll}\text { Kg } & \text { kilo } \\ \text { L } & \text { litro } \\ \text { LBV } & \text { Laboratório de Bacteriologia Vegetal } \\ \text { MAPA } & \text { Ministério da Agricultura, Pecuária e Abastecimento } \\ \text { mL } & \text { mililitro } \\ \text { mm } & \text { milímetro } \\ \mathbf{m m o l} & \text { milimol } \\ \mathbf{N} & \text { Norte }\end{array}$




$\begin{array}{ll}\mathbf{n}^{\mathbf{0}} & \text { número } \\ \mathbf{O H} & \text { hidroxila } \\ \mathbf{q S p} & \text { Potencial hidrogeniônico } \\ \mathbf{S} & \text { quantidade suficiente para } \\ \mathbf{S P} & \text { Sul } \\ \text { ton } & \text { São Paulo } \\ \mathbf{Y M E} & \text { tonelada } \\ < & \text { Yeast Malt Extract } \\ > & \text { menor } \\ = & \text { maior } \\ \sqrt{ } & \text { igual } \\ & \text { raiz quadrada }\end{array}$




\section{SUMÁRIO}

1. INTRODUÇÃO ...........................................................................................

2. OBJETIVOS

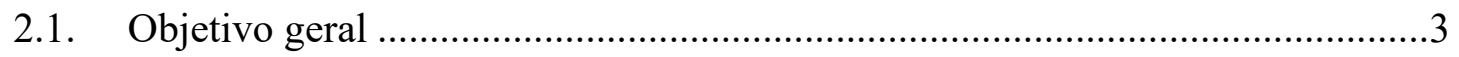

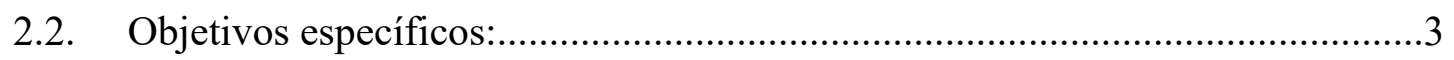

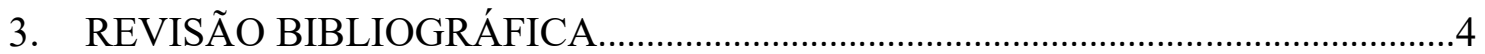

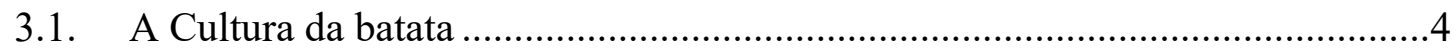

3.2. Principais problemas fitossanitários da cultura da batata no Brasil...................6

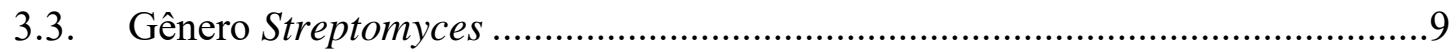

3.4. Sarna da batata e espécies de Streptomyces causadoras da doença .....................9

3.5. Ciclo da doença e epidemiologia ......................................................................11

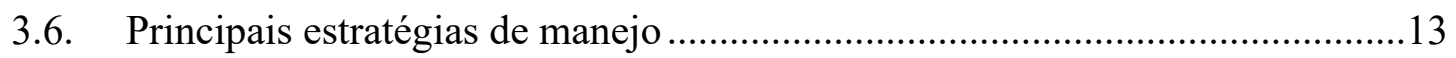

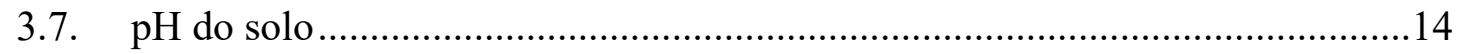

3.8. Efeito do $\mathrm{pH}$ do solo no manejo da sarna da batata.........................................15

3.9. Efeito da umidade do solo no manejo da sarna da batata ................................16

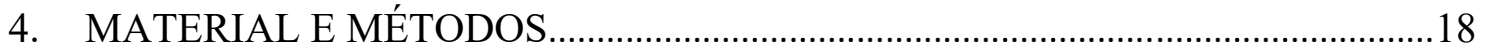

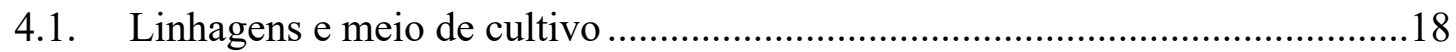

4.2. Avaliação in vitro do crescimento de Streptomyces spp. em diferentes faixas de $\mathrm{pH}$

4.3. Avaliação in vivo (casa de vegetação) da incidência e severidade da sarna da batata em diferentes faixas de $\mathrm{pH}$ do substrato inoculado com Streptomyces spp......19

4.4. Avaliação in vivo (casa de vegetação) da incidência e severidade da sarna da batata em diferentes regimes de irrigação do substrato inoculado com Streptomyces spp

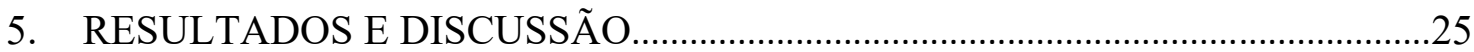

5.1. Avaliação in vitro do crescimento de Streptomyces spp. em diferentes valores de $\mathrm{pH}$ do meio de cultivo

5.2. Avaliação in vivo (casa de vegetação) da incidência e severidade da sarna da batata em diferentes valores de $\mathrm{pH}$ de substratos inoculados com Streptomyces spp. 27

5.2.1. Incidência e severidade da sarna da batata ..............................................28

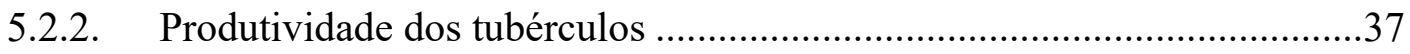

5.3. Avaliação in vivo (casa de vegetação) da incidência e severidade da sarna da batata com diferentes regimes de irrigação do substrato inoculados com Streptomyces spp......

5.3.1. Incidência e severidade da sarna da batata 
5.3.2. Produtividade de tubérculos .43

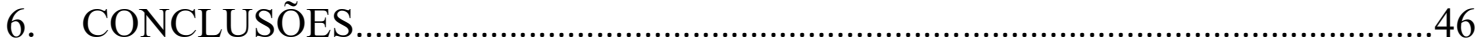

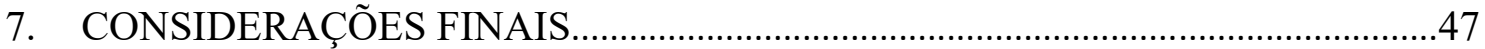

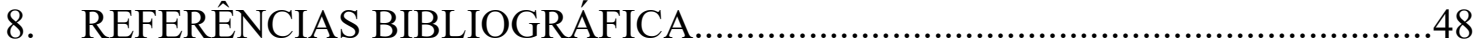




\section{INTRODUÇÃ̃}

A batata (Solanum tuberosum) é o terceiro alimento mais consumido pela humanidade, ficando atrás apenas do trigo e do arroz. No Brasil é umas das principais olerícolas consumidas e produzidas, sendo considerada grande fonte de renda e emprego no campo.

De uma forma geral, nos últimos anos a área de cultivo de batata no Brasil não sofreu grandes variações, porém houve um pequeno aumento de produtividade por área. Essa produtividade por área ainda é considerada pequena, levando-se em consideração o potencial produtivo da planta e a produtividade alcançada pelos países europeus (AGRIANUAL, 2018). A baixa produtividade pode ser atribuída a diversos fatores, sendo os principais, variedades não adaptadas ao país, batatas-semente não certificadas e contaminadas com patógenos e ataque de pragas e doenças.

Pragas e doenças representam um constante desafio aos produtores, podendo ocorrer durante todo o ciclo da cultura, causando perdas significativas diretas e elevação nos custos de produção. Dentre as doenças, as bacterianas são as que provocam os maiores danos. As bacterioses têm uma relativa superioridade em relação às doenças fúngicas, devido às dificuldades de controle químico eficiente e à alta taxa de multiplicação e adaptação das bactérias (LOPES; DUVAL, 2007). Podemos citar como de grande importância na cultura da batata, as doenças denominadas murcha bacteriana, causada por Ralstonia solanacearum; canela preta ou talo oco, ocasionada por bactérias pertencentes ao gênero Pectobacterium e Dickeya; e sarna da batata, causada por bactérias pertencentes ao gênero Streptomyces.

A sarna da batata é considerada uma das doenças mais importantes economicamente no cenário da bataticultura atual, pois os sintomas modificam a aparência dos tubérculos, dificultando ou até mesmo inviabilizando totalmente a sua comercialização. No Brasil, até pouco tempo a doença não apresentava expressividade, mas esse cenário vem mudando rapidamente. Os produtores têm sofrido com o aumento da incidência da doença, fato que pode estar relacionado com batatas-semente contaminadas, muitas vezes provenientes de importação. De acordo com a instrução normativa $n^{\circ} 12$, de 10 de junho de 2005, elaborada pelo MAPA, é permitido a entrada de tubérculos com até $5 \%$ da superfície acometida pelos sintomas de sarna. 
Ainda não existe uma forma eficiente de controle da doença, porém, várias linhas de pesquisas estão sendo seguidas para o controle da sarna da batata. Os principais métodos são o desenvolvimento de cultivares resistentes, rotação de culturas, melhoria da biota do solo utilizando agentes orgânicos, tratamentos químicos, controle biológico com antagonistas, manejo do pH e controle da umidade do solo.

As estratégias de alteração do $\mathrm{pH}$ e da umidade do solo são consideradas medidas clássicas no combate a sarna da batata (Loria, 2001). A manutenção ou a redução do $\mathrm{pH}$ do solo para valores menores que 5,2 geralmente suprimem a sarna comum causada por Streptomyces scabiei (Lambert and Loria, 1989a; Lambert et al., 2005). No entanto outras espécies patogênicas, como Streptomyces acidiscabies (Lambert and Loria, 1989b) e Streptomyces turgidiscabies (Miyajima et al., 1998) toleram valores de $\mathrm{pH}$ do solo menores que 5,2. Lacey e Wilson (2011) conseguiram bons resultados de controle da sarna comum com valores de $\mathrm{pH}$ menores que 5,0 embora Wiechel e Crump (2010) tenham concluído que o controle da doença não está relacionado com o pH do solo.

O aumento da umidade do solo, principalmente no período da tuberização, é também considerado uma forma de conter a doença. Solos úmidos propiciam uma elevada taxa de crescimento de antagonistas, maior disponibilização de manganês e concentrações reduzidas de oxigênio, condições essas que desfavorecerem o crescimento de Streptomyces patogênicos (Lewis, 1971). Segundo Wilson e colaboradores (2001), solos não irrigados no período de tuberização apresentam um grau mais elevado de sintomas da doença, porém Larkin e colaboradores (2011) relataram que a irrigação causou aumento na quantidade de sintomas da sarna da batata.

Com tais controvérsias e poucos relatos sobre o papel do $\mathrm{pH}$ do solo e regime de irrigação, o objetivo do presente trabalho foi avaliar essas variáveis com relação àincidência e severidade da sarna da batata causada por Streptomyces spp. 


\section{OBJETIVOS}

\subsection{Objetivo geral}

Avaliar o efeito do $\mathrm{pH}$ do solo e de regimes de irrigação na incidência e severidade da sarna da batata causada por Streptomyces spp.

\subsection{Objetivos específicos:}

- Avaliar in vitro o crescimento de Streptomyces spp. em meios de cultivo com diferentes valores de $\mathrm{pH}$;

- Avaliar in vivo (casa de vegetação) a incidência e a severidade da sarna da batata e a produção de tubérculos em substratos infestados com Streptomyces spp. sob condições de diferentes valores de $\mathrm{pH}$ e regimes de irrigação. 


\section{REVISÃO BIBLIOGRÁFICA}

\subsection{A Cultura da batata}

A batata (Solanum tuberosum), da família das solanáceas, apresenta sistema radicular delicado e superficial, caules aéreos e herbáceos, possui caules subterrâneos adaptados para reserva e reprodução que originam os tubérculos, parte de interesse biológico e econômico da planta (FORTES; PEREIRA, 2003).

Os primeiros registros de tubérculos petrificados foram estimados em 2000 a.C. na região de Vale Casma no Peru (UGENT et al., 1982 citado por SILVA; JADOSKI, 2015). Reforçando que a origem da batata aconteceu no continente sul americano, em uma região de altitude elevada, no sul do Peru, nas proximidades do lago Titicaca, região conhecida como Andina próxima à linha do equador, essa domesticação pode ter ocorrido há aproximadamente sete mil anos (CIP, 2006).

A introdução da batata na Europa aconteceu por volta de 1562, pelos espanhóis, porém, por diferenças de clima e fotoperíodo, não era utilizada para a alimentação devido à dificuldade de tuberização, mas apenas para fins ornamentais. Mais tarde, nos séculos XVII e XVIII, sofreu mutações genéticas, se adaptando às condições da região, sendo disseminada por toda a Europa (SILVA; JADOSKI, 2015).

Gradativamente, a batata foi elevada como o principal alimento dos europeus. Em 1845-1846, houve o aparecimento da doença conhecida como requeima, causada pelo fungo Phytophtora infestans, que devastou as plantações de batata na Irlanda, fato histórico conhecido como a grande fome da Irlanda. Devido a isso, milhões de pessoas morreram de desnutrição e uma grande parte sobrevivente migrou para outros países (HAYASHI; SALAS, 2017).

No Brasil, a introdução da cultura da batata aconteceu no século XIX, por imigrantes europeus. Os tubérculos foram levados primeiramente para o sul do país devido às condições climáticas da região, servindo de alimentação básica para os colonos até o final do século (EMATER/RS, 2008).

A batata é cultivada em uma ampla região do globo, desde $50^{\circ} \mathrm{S}$ até $65^{\circ} \mathrm{N}$ de latitude, em aproximadamente 150 países (BRADSHAW; BRYAN; RAMSEY, 2006). O plantio anual do tubérculo ocupa 20 milhões de hectares distribuídos no globo, o que resulta numa produção mundial de mais de 320 milhões de toneladas. A produtividade média varia entre 10 
e 50 toneladas/hectare e está relacionada a fatores climáticos (chuvas e temperaturas), geográficos (luminosidade), fitossanitários (pragas, doenças), genéticos (cultivares), tecnológicos (insumos, máquinas, pesquisas) e políticos (legislações e fiscalizações) (AGRIANUAL, 2018).

Nas últimas quatro décadas, a cadeia mundial da batata, assim como praticamente todos os segmentos da economia, foram diretamente transformados pela globalização. Mundialmente, a produção de batata aumentou 5\% a 10\%. Nos países mais populosos como a China e a Índia, a produção aumentou mais de 30\%. Nos países desenvolvidos, a produção se manteve estável ou cresceu até 5\% (SHIMOYAMA, 2017).

O ano de 2008 foi designado pela FAO como o ano Internacional da Batata, considerada um componente importante para mitigar a fome e a miséria nos países em desenvolvimento (FAO, 2008).

Devido às suas características nutricionais, a batata é um dos vegetais mais importantes na dieta alimentar de vários países (FAO, 2010). O seu consumo no mundo foi estimado em 32,6 kg/habitante/ano (SHIMOYAMA, 2017). A produção mundial que em 2000 era de 327,6 milhões de toneladas cresceu para 368,0 milhões de toneladas em 2013, estando entre os cinco principais itens produzidos no mundo nesse mesmo ano (FAO, 2015).

A produção brasileira de batata inglesa no ano de 2017 foi de 4,2 milhões de toneladas em um total de aproximadamente 140 mil ha de cultivo e uma média de produção de $30 \mathrm{t} / \mathrm{ha}$ (IBGE, 2018). De acordo com a publicação Agrianual (2018), nos últimos 35 anos a área plantada no Brasil sofreu redução de 13\%, passando de 150.000 hectares (1980) para menos de 130.000 hectares (2015). A produção no ano de 2015 foi aproximadamente 3,6 milhões de toneladas com produtividade média de $28,7 \mathrm{t} / \mathrm{ha}$.

A produtividade média nacional de batata cresceu de 4,95 t/ha na década de 1940 para 28,0 t/ha, na safra do ano de 2011, superando a média mundial de 19,4 t/ha (PEREIRA, 2011). Esse cenário mostra o retorno dos investimentos e das tecnologias aplicados ao setor.

Segundo projeções do agronegócio entre os anos de 2010 a 2020, realizadas pelo Ministério da Agricultura, Pecuária e Abastecimento (MAPA), a produção de batata deverá crescer a uma taxa anual de 1,51\% atingindo 4,2 milhões de toneladas e a produtividade por hectare deverá crescer 2,62\%. Além disso, a melhoria tecnológica introduzida deverá levar à redução de cerca de $1,08 \%$ da área destinada para o plantio da cultura da batata (MAPA, 2010). 
De acordo com o Agrianual (2018), no ano de 2015 os principais estados produtores foram: Minas Gerais com 1.212 mil toneladas em 38.707 ha, representando 33\% do total produzido no Brasil; Paraná com 839 mil toneladas em 30.717 ha, 23\% do total produzido; São Paulo, 656 mil toneladas em 23.575 ha, 18\% total produzido; Rio Grande do Sul com 399 mil toneladas em 19.007 ha, 11\% total produzido; Goiás com 243 mil toneladas em 5.838 ha, 7\% total produzido; Bahia com 193 mil toneladas em 4.287 ha, 5\% total produzido; e Santa Catarina com 125 mil toneladas em 5.315 ha, com 3\% do total produzido no Brasil. Mais da metade da produção nacional concentra-se na Região Sudeste.

Em termos de época de produção, a colheita da batata no Brasil ocorre em três safras distintas, distribuídas em: safra das águas: com colheita de dezembro a março, concentrando $52 \%$ da quantidade ofertada no ano; safra da seca: com colheita de abril a julho, com $30 \%$ do total produzido e, safra de inverno: colheita de agosto a novembro, totalizando $18 \%$ do abastecimento nacional. Na safra das águas, os Estados do Paraná e de Minas Gerais competem pelo mercado; na safra da seca o Paraná é o principal provedor, com pequena diferença para Minas Gerais e São Paulo, já na safra de inverno, o abastecimento fica por conta de São Paulo e Minas Gerais (GODOY, 2001).

A eficiência produtiva da cultura da batata garante elevado aproveitamento de áreas destinadas à produção de alimentos, característica importante num cenário mundial de constante crescimento populacional e segurança alimentar (FERNANDES; SORATTO, 2012).

\subsection{Principais problemas fitossanitários da cultura da batata no Brasil}

O cenário da bataticultura atual é crítico quanto aos problemas fitossanitários devido principalmente a fatores como plantios sucessivos na mesma área, não eliminação de restos culturais, manejo inadequado do solo e da água, ausência de rotação de culturas, plantios em desnível e manejo ineficiente de pragas, doenças e plantas daninhas (ZAMBOLIM et al., 2009).

A cultura da batata é suscetível a mais de 40 pragas e doenças causadas por fungos, vírus, bactérias, nematoides e insetos, podendo afetar todas as partes da planta. Esses organismos causam danos e perdas significativas na cultura, elevando os custos de produção e dificultando a comercialização (FIERS et al., 2012). De acordo com a Associação Brasileira 
de Batata (ABBA), as perdas por descarte e problemas fitossanitários podem passar de $10 \%$ da produção (SHIMOYAMA, 2014).

Dentre as principais doenças que atacam a cultura podemos citar a sarna da batata (Streptomyces spp.) e a mancha asfalto (Rhizoctonia solani). Na safra das águas podemos citar como problemas fitossanitários de grande importância a requeima (Phytophthora infestans), a canela preta (Pectobacterium spp., Dickeya spp.) e a murcha bacteriana (Ralstonia solanacearum). Já na época das secas, o maior problema é com a doença denominada pinta preta (Alternaria spp.). Com relação às pragas, podemos citar como as de maior importância a mosca branca (Bemisia tabaci), a mosca minadora (Liriomyza spp.), a traça-da-Batatinha (Phthorimaea operculella), uma grande variedade de espécies de lagartas, e a larva-alfinete (Diabrotica speciosa). Os pulgões (Myzus persicae e Macrosiphum euphorbiae) e os tripes (Thrips palmi, Thrips tabaci e Frankliniella sp.) são de grande importância devido à transmissão de diversos tipos de vírus. Além disso, existe a possibilidade de ataque pelos nematoides Melodoigyne incognita, M. japonica e Pratylenchus spp. (SCHEPERS et al., 2015; SALAS; MULLER; JOCYS, 2017).

De acordo com dados de literatura, nas últimas décadas houve um aumento significativo na quantidade de patógenos que vem gerando prejuízos à cultura da batata, conforme mostrado na Tabela 1. 
Tabela 1. Avanço dos problemas fitossanitários no Brasil, do ano de 1980 a 2012.

\begin{tabular}{|c|c|c|}
\hline & 1980 & 2012 \\
\hline Pragas & $\begin{array}{l}\text { Myzus persicae, } \\
\text { Macrosiphum euphorbiae, } \\
\text { Lyriomizar spp., } \\
\text { Phthorimaer operculella, } \\
\text { Diabrotica speciosa. }\end{array}$ & $\begin{array}{l}\text { Myzus persicae, Macrosiphum euphorbiae, Lyriomiza } \\
\text { spp., Bemisia tabaci, Phthorimae operculella, Agrotis } \\
\text { ipsilon, Spodoptera spp., Chrysodeixis inclundens, } \\
\text { Helicoverpa armigera, Frankliniella sp., Thirips } \\
\text { tabaci, Percevejos. }\end{array}$ \\
\hline Fungos & $\begin{array}{l}\text { Alternaria solani, } \\
\text { Phytophthora infestans, } \\
\text { Rhizoctonia solani. }\end{array}$ & $\begin{array}{l}\text { Alternaria solani, Alternaria grandis, Alternaria } \\
\text { alternata, Phytophthora infestans, Rhizoctonia } \\
\text { solani, Globisporangium spp., Helminthosporium } \\
\text { solani, Spongospora subterranea, Fusarium spp., } \\
\text { Sclerotinia sclerotiorum. }\end{array}$ \\
\hline Bactérias & $\begin{array}{l}\text { Ralstonia solanacearum, } \\
\text { Pectobacterium spp. }\end{array}$ & $\begin{array}{l}\text { Ralstonia solanacearum, Pectobacterium spp., } \\
\text { Dickeya sp., Streptomyces spp. }\end{array}$ \\
\hline Vírus & $\begin{array}{l}\text { Potato Y virus - PVY, } \\
\text { Potato laefroll virus - } \\
\text { PLRV. }\end{array}$ & $\begin{array}{l}\text { Potato Y virus - PVY, Potato laefroll virus - PLRV, } \\
\text { Potato virus } x \text { - PVX, Potato virus A - PVA, Potato } \\
\text { virus S - PVS, Tomato spotted wilt virus - TSWV, } \\
\text { Tomato chlorotic spot virus - TCSV, Tomato yellow } \\
\text { vein streak virus - TYVSV, Tomato severe rugose } \\
\text { virus - ToSRV, Tomato chlorosis virus - ToCV. }\end{array}$ \\
\hline Nematoides & $\begin{array}{l}\text { Meloidogyne } \\
\text { Pratylenchus spp. }\end{array}$ & Meloidogyne spp., Pratylenchus spp. \\
\hline
\end{tabular}




\subsection{Gênero Streptomyces}

O gênero Streptomyces pertence ao filo Actionobacteria, ordem Actinomycetales e classe Actinobacteria e à família Streptomycetaceae, sendo o único membro desta família (ANDERSON; WELLINGTON, 2001). É composto por bactérias Gram positivas, formadoras de esporos em cadeia e pseudomicélio filamentoso, estruturas geralmente encontradas em fungos (LORIA et al. 2001). Os seus filamentos penetram e colonizam a matéria orgânica do solo, quebrando-a em moléculas assimiláveis utilizadas para a nutrição, proporcionando o crescimento da colônia (LORIA; KERS; JOSHI, 2006). Apresentam cadeia de esporos, espiralada ou retilínea, sendo essa uma característica taxonômica importante (LORIA et al. 2001). Esses esporos podem ser disseminados pela água ou por nematoides e artrópodes presentes no solo, germinam independentemente de nutrientes e formam micélios ramificados multinucleados (LORIA; KERS; JOSHI, 2006).

De acordo com Euzeby (2018), esse gênero está composto por 848 espécies identificadas, em sua maioria saprófitas que vivem no solo. Tem um papel importante no ciclo de carbono, pois produzem enzimas hidrolíticas que degradam polímeros derivados de plantas e/ou animais como celulose, lignina e quitina (LORIA; KERS; JOSHI, 2006). Além disso, espécies desse gênero são conhecidas também pela capacidade de produzir antibióticos, participando de aproximadamente $65 \%$ da produção total dos antibióticos naturais (MOHANRAJ; SEKAR, 2013). Ainda, há espécies que tem sido utilizadas em programas de controle biológico no combate a fungos e bactérias fitopatogênicas (EVANGELISTA-MARTINEZ, 2014)..

Do total de espécies descritas do gênero, poucas são consideradas fitopatogênicas e todas estão associadas à sarna da batata. As infecções são limitadas aos órgãos subterrâneos (tubérculos) e geralmente com sintomas necróticos (LORIA et al., 1997). Embora os principais danos econômicos sejam causados na cultura da batata, já foram relatados casos de sarna ocorrendo também no rabanete, beterraba, cenoura e nabo (LOPES; ZAMBOLIM, 2007).

\subsection{Sarna da batata e espécies de Streptomyces causadoras da doença}

A sarna da batata é causada por diferentes espécies do gênero Streptomyces, que apresentam como característica formar filamentos em algum estágio de seu desenvolvimento (DIETZ, 1986), ou seja, apresentam características morfológicas tanto de fungo como de 
bactérias. Os sintomas são quase que exclusivos aos tubérculos, podendo afetar raízes, estolões e hastes em contato com o solo (LORIA; KERS; JOSHI, 2006).

Os sintomas da doença e seu grau de severidade podem variar muito, dependendo de fatores como espécie ou linhagem do patógeno envolvida, quantidade desse patógeno no solo, cultivar da batata, bem como condições ambientais ótimas para desenvolvimento dos sintomas (MULDER; TURKENSTEEN, 2005). De uma forma geral, os sintomas se caracterizam por pequenas lesões arredondadas, marrom avermelhadas no início podendo depois ficar enegrecidas, e podem ser superficiais ou em graus mais extremos, com profundidade de até um cm (LOPES; ZAMBOLIM, 2007). As lesões nos tubérculos podem também variar no aspecto (lisa, áspera, reticulada ou em forma de estrela), na profundidade (superficial, erumpente ou profunda) e na coloração (pardo clara ou escura e avermelhada) (MULDER; TURKENSTEEN, 2005).

De acordo com Lambert e Loria (1989a) Streptomyces scabiei é a principal espécie causadora da sarna comum na batata, encontrada em solos secos, neutros ou alcalinos e distribuída por todo o mundo. Além disso, já foram descritas outras 12 espécies de Streptomyces associadas à doença: S. acidiscabies e S. caviscabies/S. setonii (MILLARD; BURR, 1926) descritas no Canadá; S. turgidiscabies com seu primeiro registro no Japão; S. europaeiscabiei e S. stelliscabiei ambas descritas na França; S. reticuliscabiei isolada na França (BOUCHEK-MECHICHE et al., 2000); S. luridiscabiei, S. puniciscabiei e S. niveiscabiei isoladas na Coréia (PARK et al., 2003); S. aureofaciens (FAUCHER et al., 1993) e S. sampsonii (LAMBERT; LORIA, 1989a). Ainda, há Streptomyces ipomoeae que ataca batata-doce (PERSON; MARTIN, 1940).

No Brasil, S. scabiei é a espécie mais comum e amplamente distribuída em todo o território, seguida de S. ipomoeae e S. caviscabies/S. setonii também ocorrem no Brasil, enquanto que as espécies $S$. europaeiscabiei e S. sampsonii estão restritas apenas ao estado de São Paulo (CORRÊA, 2011).

De acordo com Dias e Iamauti (1997), os prejuízos diretos do patógeno à cultura da batata são diretos, pois afetam a estética do produto final, diminuindo o seu valor comercial ou até mesmo inviabilizando a sua comercialização. Além disso, predispõem o tubérculo ao ataque de outros microrganismos (LOPES; ZAMBOLIM, 2007).

A sarna da batata ocorre em todas as áreas cultivadas com batata no mundo (BERIAM; ALMEIDA, 2016). De acordo com Slack (1991), essa doença foi considerada a quarta enfermidade mais importante da cultura na América do Norte. Hill e Lazarovits (2005) 
estimaram perdas de 15,3 a 17,3 milhões de dólares na safra do Canadá no ano de 2002, cerca de $82 \%$ da produção foi afetada pelo patógeno. Na Austrália, os custos com a sarna da batata ficaram estimados em US\$ 3,66 mil dólares por ha australiano (WILSON, 2004).

No Brasil, a frequência com que essa doença tem ocorrido em lavouras é causa de preocupação crescente (ZAMBOLIM et al., 2009). Ainda não existe na literatura dados que mensurem os prejuízos causados pela doença no país, mas em conversas informais com os produtores, esse prejuízo pode chegar a $100 \%$ da área atacada pelo patógeno, resultando na não comercialização do produto final.

\subsection{Ciclo da doença e epidemiologia}

As estruturas vegetativas ou os esporos da bactéria Streptomyces permanecem no solo em aglomerados próximos a restos de cultura e produzem hifas que se desenvolvem radialmente, o que facilita sua dispersão. Os esporos podem sobreviver em solos secos por longos períodos (MANZER; STORCH; SEWELL, 1984). O agente patogênico causador da sarna comum penetra nos tecidos das plantas através das lenticelas ou através de pequenos ferimentos (MULDER; TURKENSTEEN, 2005). No entanto, a entrada nos tubérculos e nas raízes pode ocorrer por hifas secundárias, que não requerem aberturas naturais como das lenticelas (TARKOWSKI; VEREECKE, 2014). No período da tuberização, o tubérculo se mostra mais suscetível à infecção devido às lenticelas serem jovens e não estarem totalmente suberizadas, mas à medida que os tubérculos ficam mais velhos tornam-se mais resistentes (ADAMS; LAPWOOD, 1978).

No início da doença, o patógeno coloniza os espaços intercelulares e depois os intracelulares (ADAMS; LAPWOOD, 1978). A bactéria cresce entre as camadas da periderme e produz fitotoxinas, como a taxtomina, responsável pela morte celular e consequentemente a formação de uma camada corticosa ao redor do tecido infectado (AGRIOS, 1997). Essa camada corticosa funciona como uma barreira protetora que permite o desenvolvimento da bactéria. Dessa forma, o crescimento da camada corticosa empurra a periderme infectada para fora tornando a superfície áspera e suberificada, características essa da doença "sarna" (BABCOCK; ECKWALL; SCHOTTEL, 1993). O tamanho da lesão está diretamente ligado com o momento da infecção devido o ciclo da doença acontecer muitas vezes durante o ciclo da planta; quanto antes a infecção ocorrer maior será a extensão da lesão (RODRIGUES NETO; DESTÉFANO; SHIMOYAMA, 2008). 


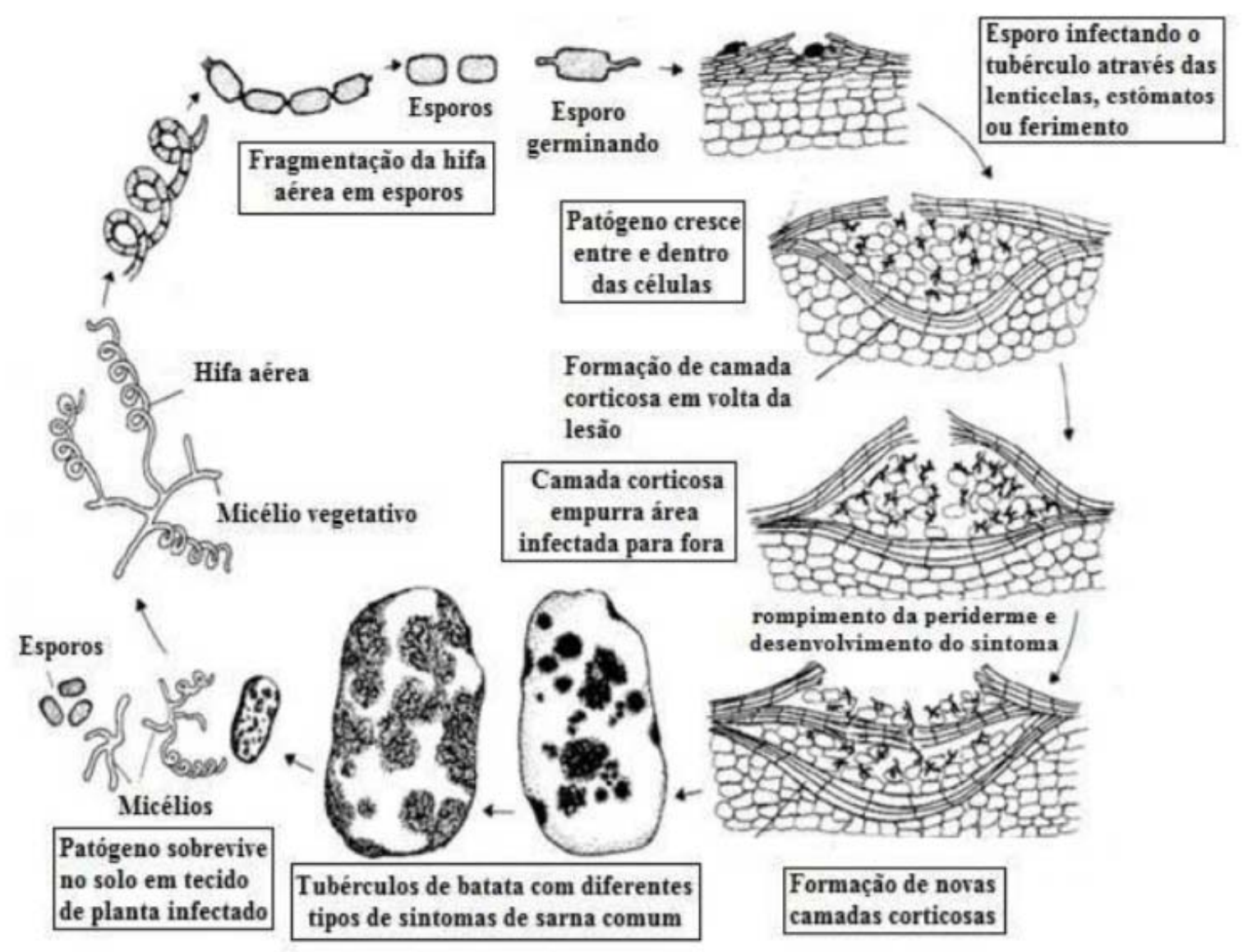

Figura 1. Ciclo da sarna da batata. Fonte: Agrios (1997), modificado por Corrêa (2011).

A sarna da batata pode ser eficientemente disseminada a longas distâncias por meio de batatas-semente contaminadas ou, ainda, a curtas distâncias através de máquinas agrícolas com solo contaminado aderido, pela água e pelo vento (ZAMBOLIM et al., 2009).

Segundo Lopes e Zambolim (2007), depois do patógeno ser introduzido em uma área, dificilmente o mesmo pode ser eliminado do solo, pois ele pode sobreviver em restos não decompostos de plantas de batata, em soqueiras ou na própria matéria orgânica do solo.

A amplitude de temperatura em que a doença ocorre situa-se entre $5^{\circ} \mathrm{C}$ e $40^{\circ} \mathrm{C}$, sendo ótima entre $25^{\circ} \mathrm{C}$ e $30^{\circ} \mathrm{C}$. Dessa forma, o fator temperatura não é limitante ao crescimento da bactéria, (LOPES; ZAMBOLIM, 2007)

Um dos fatores mais importantes no desenvolvimento da sarna é o teor de água no solo. Em solos úmidos, bactérias nativas do solo colonizam as lenticelas mais rapidamente que linhagens de Streptomyces spp. e após a colonização essas bactérias protegem a planta contra a infecção do patógeno. Quando o solo está mais seco, essas bactérias nativas não têm 
capacidade de alcançar as lenticelas, enquanto S. scabiei, por ser uma bactéria filamentosa, consegue se movimentar e colonizar o tubérculo (ZAMBOLIM et al., 2009).

Com relação às condições de pH do solo, de acordo com Lopes e Zambolin (2007), o pH do solo mais adequado para a sobrevivência de $S$. scabiei está entre 5,0 e 7,5, enquanto $S$. acidiscabieis sobrevive bem em $\mathrm{pH}$ abaixo de 4,5.

\subsection{Principais estratégias de manejo}

Levando em consideração a complexidade do patógeno envolvido na doença, devem ser adotadas medidas preventivas, que realizadas em conjunto podem amenizar os danos.

A presença da bactéria em tubérculos-semente pode ser relevante para a disseminação de espécies patogênicas de Streptomyces para regiões livres do patógeno (WILSON; RANSON; PEMBERTON, 1999). A sarna da batata pode estar sendo disseminada no Brasil por meio de material propagativo vindo de outros países ou até mesmo de outros estados, e deste modo, torna-se necessário que medidas fitossanitárias sejam tomadas com relação ao intercâmbio desse material. Assim, a certificação dos tubérculos-semente torna-se uma medida importante que pode garantir a sanidade do material vegetal (ZAMBOLIM et al., 2009).

O método mais confiável de manejo seria o desenvolvimento de cultivares resistentes à sarna, porém não se tem conhecimento de cultivar comercialmente disponível completamente resistente à doença, uma vez que os mecanismos e a base genética envolvidos na tolerância à sarna ainda não são totalmente conhecidos. Estudos indicam que múltiplos genes podem estar envolvidos na resistência ou na suscetibilidade das cultivares (DEES; SLETTEN; HERMANSEN, 2013). O conteúdo de açúcares redutores (glicose e frutose) presentes na pele do tubérculo está sendo correlacionado com a severidade da sarna comum e com a capacidade de glicosilação da taxtomina A, deixando-a parcialmente inativa, sendo proposta como um mecanismo de resistência entre as cultivares (ACUÑA et al., 2001). Nesse sentido, a taxtomina A vem se mostrando promissora como agente seletivo para eliminar a progênie sensível à sarna em populações de melhoramento genético de batata (HILTUNEN et al., 2011).

Outro ponto levado em consideração no manejo da sarna da batata é a rotação de culturas, utilizada com estratégia para diminuir a quantidade do inóculo de Streptomyces no solo. Este fator de manejo não está relacionado somente com as características fitossanitárias, 
mas também com a fertilidade e estruturação do solo. $\mathrm{O}$ uso da rotação com cereais e gramíneas não hospedeiras de Streptomyces, como arroz e trigo, por exemplo, possibilitaram a redução da população do patógeno (JADOSKI et al., 2009). Porém, nem sempre é uma medida eficiente, pois a fitobactéria pode se manter por muito tempo no solo mesmo sem nenhum hospedeiro, através dos seus esporos de resistência. Culturas de beterraba, cenoura, nabo, rabanete e batata-doce são consideradas hospedeiras de Streptomyces spp. e não devem ser utilizadas na rotação de culturas, pois podem aumentar o inóculo da área de plantio (RODRIGUES NETO; DESTÉFANO; SHIMOYAMA, 2008).

O controle biológico pode ser um novo aliado contra a sarna da batata. Camparoni (2015) estudando linhagens de Bacillus subtilis no controle de S. scabiei conseguiu resultados positivos na taxa de inibição de crescimento do patógeno. Relato de literatuda mostra que uma linhagem de Bacillus sp. sunhua reduziu de 35\% a 75\% a taxa de infecção da sarna (HAN et al., 2005). Estudos com Bacillus amyloliquefaciens BAC03 demonstraram também redução na severidade da doença de 17 a 57\%, melhorando inclusive o crescimento dos tubérculos de batata (MENG et al., 2013). Além disso, espécies de Streptomyces não patogênicas podem ser consideradas como potenciais agentes de controle biológico contra a sarna devido à capacidade de produção de antibióticos e enzimas extracelulares (DOUMBOU et al., 2001).

De acordo com Zambolim et al. (2009), o controle químico é atualmente a medida de controle preconizada no Brasil contra a sarna, entretanto, Hosny e colaboradores (2014) relataram que nenhum produto químico com total eficácia está disponível no mercado mundial até o momento. Resultados encontrados com relação à eficácia do tratamento químico de tubérculos-semente demostraram que fungicidas como Fluazinam, Flusulfamida (doses elevadas), Fenipiclonil, Pentacloronitrobenzeno e Mancozeb proporcionaram bons resultados no controle da sarna (WILSON; RANSON; PEMBERTON, 2008)

\section{7.pH do solo}

$\mathrm{O}$ pH ou potencial hidrogeniônico do solo é a determinação da concentração de íons $\mathrm{H}^{+}$na solução do solo identificando o grau ou intensidade da acidez ativa ou da alcalinidade do solo. O solo de caráter ácido é aquele que apresenta $\mathrm{pH}$ abaixo de 7,0; sendo que $\mathrm{pH}$ 7,0 é considerado neutro e $\mathrm{pH}$ maior que 7,0, alcalino. Naturalmente, em pH ácido haverá excesso de $\mathrm{H}^{+}$a ser adsorvido, enquanto que em $\mathrm{pH}$ alcalino haverá excesso de $\mathrm{OH}^{-}$. 
A acidificação do solo consiste na remoção dos cátions básicos de cálcio $\left(\mathrm{Ca}^{2+}\right)$, magnésio $\left(\mathrm{Mg}^{2+}\right)$, potássio $\left(\mathrm{K}^{+}\right)$e sódio $\left(\mathrm{Na}^{+}\right)$do sistema solo, substituindo-os por alumínio $\left(\mathrm{Al}^{3+}\right)$ e hidrogênio $\left(\mathrm{H}^{+}\right)$. Nos solos ácidos existem problemas de deficiência e/ou toxidez nutricional e baixa capacidade de troca catiônica, além da interferência na atividade biológica do solo (FONTES, 1997).

A concentração de $\mathrm{H}^{+}$na solução do solo, mesmo com valor de $0,1 \mathrm{mmol} \mathrm{L}^{-1}$ que corresponde a $\mathrm{pH} 4,0$, não é fator limitante de crescimento e desenvolvimento das plantas, desde de que haja suprimento adequado dos nutrientes e ausência de elementos em concentrações tóxicas. Essa situação não se mantém em solos naturalmente ácidos, que apresentam teores de alumínio $\left(\mathrm{Al}^{3+}\right.$ e Manganês $\left(\mathrm{Mn}^{2+}\right.$ tóxicos para as plantas (SOUSA et al., 2007).

\subsection{Efeito do pH do solo no manejo da sarna da batata}

De forma natural alguns solos previnem o crescimento de patógenos ou inibem as suas atividades patogênicas, sendo chamados de solos supressivos. Existem solos que apresentam capacidade de reduzir a quantidade do inóculo e suas atividades saprofíticas, enquanto outros reduzem a severidade da doença, mesmo com alta infestação do patógeno e sua capacidade de sobrevivência (BETTIOL et al., 2009).

Segundo Bettiol e colaboradores (2009), a supressividade pode ser dividida em dois tipos, de longa e de curta duração. Supressividade de curto prazo pode ser resultado de alterações em práticas agrícolas, como fertilização, correção de acidez, cultivo mínimo, monocultura, incorporação de matéria orgânica e introdução de antagonistas, podendo desaparecer rapidamente com novas alterações. Supressividade de longo prazo pode ser resultado de propriedades físicas e químicas estáveis do solo, sendo observada por muitos anos, muitas vezes desde o início da exploração do solo.

Vários fatores impedem que um patógeno se estabeleça no solo, sendo estes físicos, químicos e biológicos, como teores de argila, tamanho de agregados, $\mathrm{pH}$, nutrientes, condutividade elétrica e comunidade microbiana (HÖPER; ALABOUVETTE, 1996).

Segundo Hõper e Alabouvette (1996), solos com pH extremos, ácidos ou alcalinos são normalmente supressivos para algumas doenças. Com valores de $\mathrm{pH}$ abaixo de 3,8 e 4,5, doenças causadas por S. scabiei, Phytophthora spp., Gaeumannomyces graminis var. tritici, Rhizoctonia solani, Thielaviopsis basicola, Verticillium spp. e Fusarium solani são 
suprimidas. Em solos com pH entre 5,0 e 7,0, que são os valores atingidos após a calagem dos solos cultivados, essa correlação de supressão não se mantém.

A manutenção ou redução do $\mathrm{pH}$ do solo para valores menores que 5,2 geralmente suprimem a sarna comum, variando na prática dependendo de outros fatores como cultivar de batata, potencial do inóculo, tipo de solo e umidade (LAMBERT; POWELSON; STEVENSON, 2005).

A adubação do solo também pode estar relacionada com a diminuição do pH do solo. $\mathrm{O}$ fertilizante sulfato de amônio além de diminuir o $\mathrm{pH}$ do solo, eleva a concentração de alumínio solúvel, diminuindo a incidência da sarna em até 50\% (MIZUNO; YOSHIDA; TADANO, 2000). Entretanto, de acordo com os autores, a eficácia desse composto depende do tipo de solo em questão

Existem alguns estudos realizados nesse seguimento avaliando-se o $\mathrm{pH}$ como medida de controle da sarna da batata. Lacey e Wilson (2011) avaliaram a incidência de S. scabiei na Austrália em um solo ferroso, onde foram levadas em consideração as variáveis pH do solo, níveis de $\mathrm{Mg}, \mathrm{Ca}$ e $\mathrm{K}$. De acordo com os autores, o $\mathrm{pH}$ foi o que apresentou maior relação com a diminuição da porcentagem de lesões dos tubérculos em decorrência da sarna. Com o pH menor que 5,0; nove das dez amostras analisadas não apresentaram lesões, mas com pH acima de 5,0; 15 das 25 amostras apresentaram sintomas da doença.

Waterer (2002) realizou um estudo durante os anos de 1995 a 1998, onde o pH foi variado de 7,0 a 9,0; e concluiu que entre 8,5 e 9,0 os níveis de infecção por sarna foram reduzidos significativamente. Entretanto, um dado importante que deve ser ressaltado é que no ano de 1998 o experimento foi conduzido em uma área com baixa concentração de Streptomyces, resultando em baixo ataque independente do $\mathrm{pH}$ testado.

Num outro estudo, Wiechel e Crump (2010), avaliaram durante três anos a relação do aumento do $\mathrm{pH}$ do solo com a incidência da sarna comum em campos com elevados níveis de contaminação do patógeno e concluíram que o aumento da incidência foi sazonal, dependeu do ano, não estando diretamente ligado ao $\mathrm{pH}$ do solo apenas.

\subsection{Efeito da umidade do solo no manejo da sarna da batata}

Uma das medidas clássicas citadas para a redução da sarna da batata é a manutenção da boa umidade do solo, principalmente no período da tuberização. Os solos úmidos propiciam elevada taxa de crescimento de microrganismos antagonistas, e estes se movem 
mais rapidamente pelas películas de água do solo úmido que as espécies de Streptomyces patogênicas, colonizando primeiro as lenticelas e competindo com o patógeno. A maior umidade do solo aumenta a disponibilidade de manganês e diminui as concentrações de oxigênio podendo ajudar na diminuição da incidência da doença. Em solos secos, além da não proteção das lenticelas por microrganismos antagonistas durante o crescimento dos tubérculos são produzidos ferimentos pelos quais os patógenos podem penetrar mais facilmente (LEWIS, 1971).

Wilson, Pemberton e Ransom (2001), na região da Tasmânia, avaliaram o efeito da umidade do solo na incidência da sarna causada por S. scabiei e concluíram que o tratamento que recebeu menos água durante o período de tuberização mostrou uma incidência significativamente maior da doença do que outros tratamentos que receberam mais umidade durante o mesmo período. Johansen, Dees e Hermansen (2014), em estudo realizado na Noruega entre os anos de 2009 e 2011, avaliaram o efeito da umidade do solo na incidência da sarna causada pelas espécies $S$. turgidiscabies e S. europaescabiei. Foram testados solos secos ( $8 \%$ de água), normais (15\%) e úmidos (22\%), mantidos durante quatro semanas a partir do início do processo de tuberização. No ano de 2009 não foram verificadas diferenças significativas entre os tratamentos, no ano de 2010 a porcentagem das lesões do tratamento com o solo seco foi significativamente maior que os tratamentos normais e úmidos, já no ano de 2011 os tratamentos secos e normais apresentaram mais lesões que o tratamento úmido. Esses resultados foram contrastados por Larkin e colaboradores. (2011), que após um estudo durante três anos, concluíram que os tratamentos com irrigação apresentaram níveis mais elevados de sarna do que os tratamentos sem irrigação, com aumento de 10 a $50 \%$ de incidência da doença. 


\section{MATERIAL E MÉTODOS}

\subsection{Linhagens e meio de cultivo}

As linhagens utilizadas nesse estudo foram cedidas pela Coleção de Culturas de Fitobactérias do Instituto Biológico (IBSBF), Laboratório de Bacteriologia Vegetal (LBV) do Centro Avançado de Pesquisa em Proteção de Plantas e Saúde Animal (CAPSA), Instituto Biológico, Campinas, São Paulo (Tabela 2).

As linhagens foram cultivas em meio de cultivo YME (extrato de levedo $4 \mathrm{~g}$, extrato de mate $10 \mathrm{~g}$, dextrose $4 \mathrm{~g}$, ágar água $18 \mathrm{~g}$, água destilada q.s.p. $1000 \mathrm{~mL}$ ), pH 7,0, a $28{ }^{\circ} \mathrm{C}$ por 14 dias.

Tabela 2. Linhagens de Streptomyces spp. utilizadas no estudo

\begin{tabular}{lccc}
\hline IBSBF & Espécie & Procedência & Cultivar \\
\hline 2950 & S. scabiei & Canoinhas (SC) & Asterix \\
2959 & Streptomyces sp. & Canoinhas (SC) & Ágata \\
$2110^{\mathrm{T}}$ & S. acidiscabies & Canadá & Desconhecida \\
2400 & S. caviscabies & Itapetininga (SP) & Mondial \\
$2051^{\mathrm{T}}$ & S. caviscabies & Canadá & Desconhecida \\
$2023^{\mathrm{T}}$ & S. europaescabiei & França & Desconhecida \\
\hline
\end{tabular}

IBSBF (Coleção de Culturas de Fitobactérias do Instituto Biológico, Campinas, SP, Brasil).

\subsection{Avaliação in vitro do crescimento de Streptomyces spp. em diferentes faixas de pH}

Baseado em dados de literatura foram selecionadas os seguintes valores de $\mathrm{pH} 4,0$; 4,$5 ; 5,0 ; 6,0 ; 7,0 ; 8,0$ e 9,0, sendo o $\mathrm{pH} 7,0$ considerado o controle dos tratamentos. Os testes foram realizados em placas de Petri, contendo meio de cultivo YME corrigido para cada uma das faixas de $\mathrm{pH}$ selecionadas com solução de $\mathrm{NaOH}$ (para aumentar) e $\mathrm{HCl}$ (para diminuir). As medições dos valores de $\mathrm{pH}$ foram realizadas antes da autoclavagem, podendo ter ocorrido pequenas modificações nestes valores. As linhagens de Streptomyces (Tabela 2) foram cultivadas em placas de Petri contendo o meio YME a $28{ }^{\circ} \mathrm{C}$ por sete dias. Após, recortou-se um disco de cinco $\mathrm{cm}^{2}$ do crescimento de cada linhagem e adicionou-se no centro das placas 
contendo o meio YME em diferentes faixas de $\mathrm{pH}$. As avaliações do crescimento bacteriano foram realizadas após sete e 14 dias da inoculação, sendo realizadas as medidas da largura e do comprimento $(\mathrm{cm})$ do halo de crescimento das linhagens em cada tratamento.

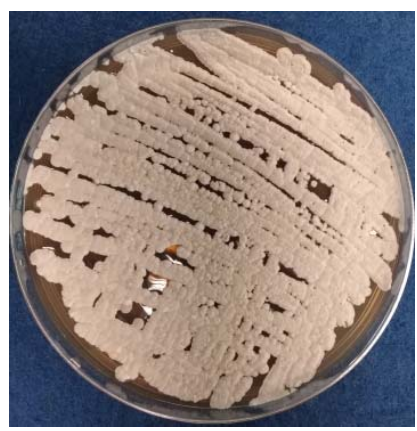

Crescimento bacteriano em meio de cultivo YME em $\mathrm{pH} 7,0$ incubados a $28^{\circ} \mathrm{C}$ por 14 dias

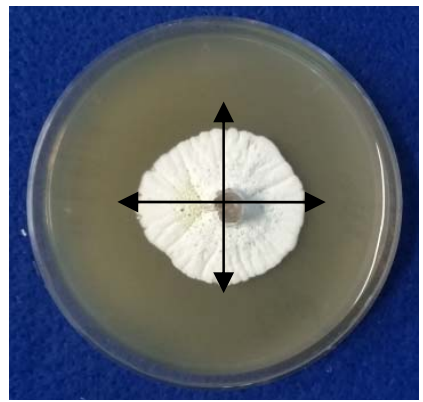

Crescimento bacteriano avaliado através das medidas da largura e comprimento $(\mathrm{cm})$ conforme indicações das setas.
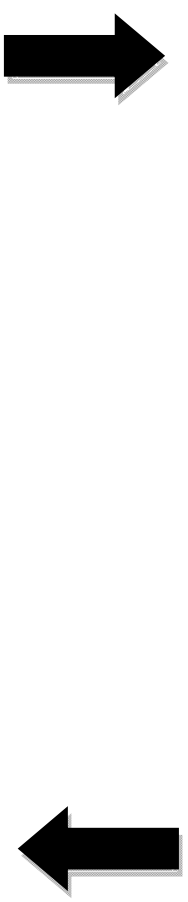

Disco de aproximadamente cinco $\mathrm{mm}^{2}$ do crescimento bacteriano sendo recortado com a base de uma ponteira descartável
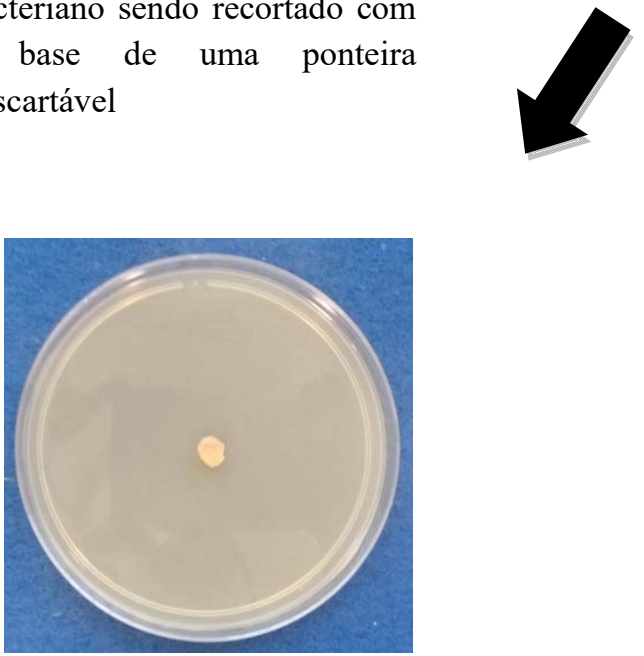

Disco de crescimento bacteriano colocado no centro de uma outra Placa de Petri com meio de cultivo no $\mathrm{pH}$ a ser testado

Figura 2. Testes de pH in vitro. Fonte: LBV

\subsection{Avaliação in vivo (casa de vegetação) da incidência e severidade da sarna da batata em diferentes faixas de pH do substrato inoculado com Streptomyces spp.}

Foram selecionados os seguintes valores de $\mathrm{pH}$ do substrato: 4,0;4,5; 5,5; 6,5; 7,5 para os testes com as linhagens de Streptomyces acidiscabies IBSBF $2110^{\mathbf{T}}$, Streptomyces scabiei IBSBF 2950, Streptomyces sp. IBSBF 2959 e Streptomyces caviscabies IBSBF $2051^{\mathbf{T}}$. 
O plantio foi realizado em casa de vegetação do Laboratório de Bacteriologia Vegetal, Centro Avançado de Pesquisas em Proteção de Plantas e Saúde Animal (CAPSA) do Instituto Biológico, Campinas, SP no ano 2018, no inverno (junho a agosto), para todas as espécies estudadas. As temperaturas nesse período apresentaram mínima de $13,1^{\circ} \mathrm{C}$ e máximade $26,8^{\circ}$ C. De forma complementar foram realizados testes para as espécies de S. acidiscabies e S. scabiei no verão (dezembro a março) com temperatura mínima de $19,2^{\circ} \mathrm{C}$ e máxima de $30,9^{\circ} \mathrm{C}$.

A cultivar utilizada foi a Ágata, por ser considerada a mais plantada no Brasil e mais utilizada para consumo de mesa. Os minitubérculos-semente de batata foram doados pela empresa Solei Papa Tecnologia, Vargem Grande do Sul, SP, Brasil.

Nos experimentos foi utilizado substrato esterilizado para plantas à base de turfa de Sphagno, cedido gentilmente pela empresa Carolina Soil, já com a correção de $\mathrm{pH}$, ou seja, sem a presença de qualquer microrganismo.

As análises das características químicas dos substratos utilizados nos ensaios foram efetuadas pelo Laboratório de Solos do Instituto Agronômico de Campinas (IAC) (Tabela 3).

As linhagens de Streptomyces testadas foram cultivadas em placas de Petri contendo meio YME a $28{ }^{\circ} \mathrm{C}$ por 14 dias e para a inoculação do substrato utilizou-se uma placa por vaso. Após o crescimento, o inóculo foi raspado, adicionado a $250 \mathrm{~mL}$ de Solução Say $2 \mathrm{X}$ esterilizada (40 g de sacarose; 2,4 $\mathrm{g}$ de asparagina; $1,2 \mathrm{~g}$ de $\mathrm{K}_{2} \mathrm{HPO}_{4}$ e $20 \mathrm{~g}$ de extrato de levedura; q.s.p. 1 litro de água destilada esterilizada) e transferido para saco plástico contendo $1.500 \mathrm{~cm}^{3}$ de vermiculita esterilizada. $\mathrm{O}$ inóculo bacteriano em vermiculita foi mantido a $28^{\circ}$ C por mais 14 dias, agitando-se os sacos em dias alternados durante a incubação. vermiculita esterilizada. O inóculo bacteriano em vermiculita foi mantido a $28{ }^{\circ} \mathrm{C}$ por mais 14 dias, agitando-se os sacos em dias alternados durante a incubação.

Após o crescimento, cerca de $500 \mathrm{~cm}^{3}$ do inóculo de Streptomyces crescido em vermiculita foram adicionados a $6.000 \mathrm{~cm}^{3}$ do substrato, cuidadosamente homogeneizado e separado em cinco partes iguais de $1.300 \mathrm{~cm}^{3}$. No plantio, vasos de $2 \mathrm{~L}$ com 15 centímetros de diâmetro foram parcialmente preenchidos com $700 \mathrm{~cm}^{3}$ do substrato (sem inóculo), um volume de $1.300 \mathrm{~cm}^{3}$ da mistura de substrato com inóculo foi adicionado ao vaso e um minitubérculo-semente de batata tipo I foi plantado na camada contendo o inóculo. Os vasos foram mantidos em casa de vegetação (Figura 3) e as plantas regadas com $100 \mathrm{~mL}$ de água em dias alternados. Como controles negativos foram utilizados vasos com substrato em cada faixa de pH testado sem adição do inoculo (Modificado de WANNER, 2007). 
Tabela 3. Caracterização química dos substratos em diferentes valores de $\mathrm{pH}$.

\begin{tabular}{|c|c|c|c|c|c|c|c|c|}
\hline \multirow{2}{*}{ Substrato } & \multirow[t]{2}{*}{ pH } & EC & $\begin{array}{c}\text { N- } \\
\text { Nitrato }\end{array}$ & Fósforo & Cloreto & Enxofre & $\begin{array}{c}\text { N- } \\
\text { Amônia }\end{array}$ & Potássio \\
\hline & & $\mathrm{dS} / \mathrm{m}$ & \multicolumn{6}{|c|}{$\mathrm{mg} / \mathrm{L}$} \\
\hline $\mathrm{pH} 4,0$ & 3,7 & 0,2 & 0,7 & 1,0 & 13,1 & 9,7 & 3,1 & 0,2 \\
\hline $\mathrm{pH} 4,5$ & 4,4 & 0,1 & 0,9 & 0,4 & 3,9 & 2,4 & 3,5 & 0,01 \\
\hline $\mathrm{pH} 5,5$ & 5,2 & 0,2 & 0,6 & 0,3 & 15,6 & 7,5 & 0,3 & $<0,01$ \\
\hline pH 6,5 & 6,7 & 0,2 & 0,3 & 0,2 & 14,9 & 6,7 & 0,5 & $<0,01$ \\
\hline $\mathrm{pH} 7,5$ & 7,0 & 0,2 & 0,8 & 0,2 & 5,3 & 2,2 & 0,7 & 0,4 \\
\hline \multirow{2}{*}{ Substrato } & Sódio & Cálcio & Magnésio & Boro & Cobre & Ferro & Manganês & Zinco \\
\hline & \multicolumn{8}{|c|}{$\mathrm{mg} / \mathrm{L}$} \\
\hline $\mathrm{pH} 4,0$ & 8,4 & 7,8 & 3,4 & 0,02 & 0,1 & 0,3 & 0,1 & 0,2 \\
\hline $\mathrm{pH} 4,5$ & 1,6 & 2,3 & 1,1 & 0,01 & 0,1 & 0,2 & 0,01 & 0,02 \\
\hline $\mathrm{pH} 5,5$ & 10,5 & 6,0 & 4,9 & 0,02 & 0,2 & 0,3 & 0,04 & 0,04 \\
\hline $\mathrm{pH} 6,5$ & 9,6 & 8,2 & 7,8 & 0,01 & 0,2 & 0,2 & 0,03 & 0,03 \\
\hline $\mathrm{pH} 7,5$ & 4,6 & 10,9 & 4,7 & 0,1 & 0,2 & 0,1 & 0,02 & 0,04 \\
\hline
\end{tabular}

$\mathrm{K}, \mathrm{Ca}, \mathrm{Mg}, \mathrm{P}, \mathrm{S}, \mathrm{Cu}, \mathrm{Fe}, \mathrm{Mn}, \mathrm{Zn}$ : ICP-OES;

Após o plantio e durante o desenvolvimento das plantas foi efetuada a conferência do $\mathrm{pH}$ de cada tratamento através do método de Pour Through, que consiste em determinar o $\mathrm{pH}$ no lixiviado obtido uma hora após a irrigação dos potes preenchidos com substrato. Para a coleta foram adicionados $100 \mathrm{~mL}$ de água destilada ao substrato e recolhido em recipiente para leitura em medidor de pH de bancada (LEBUDE; BILDERBACK, 2009).

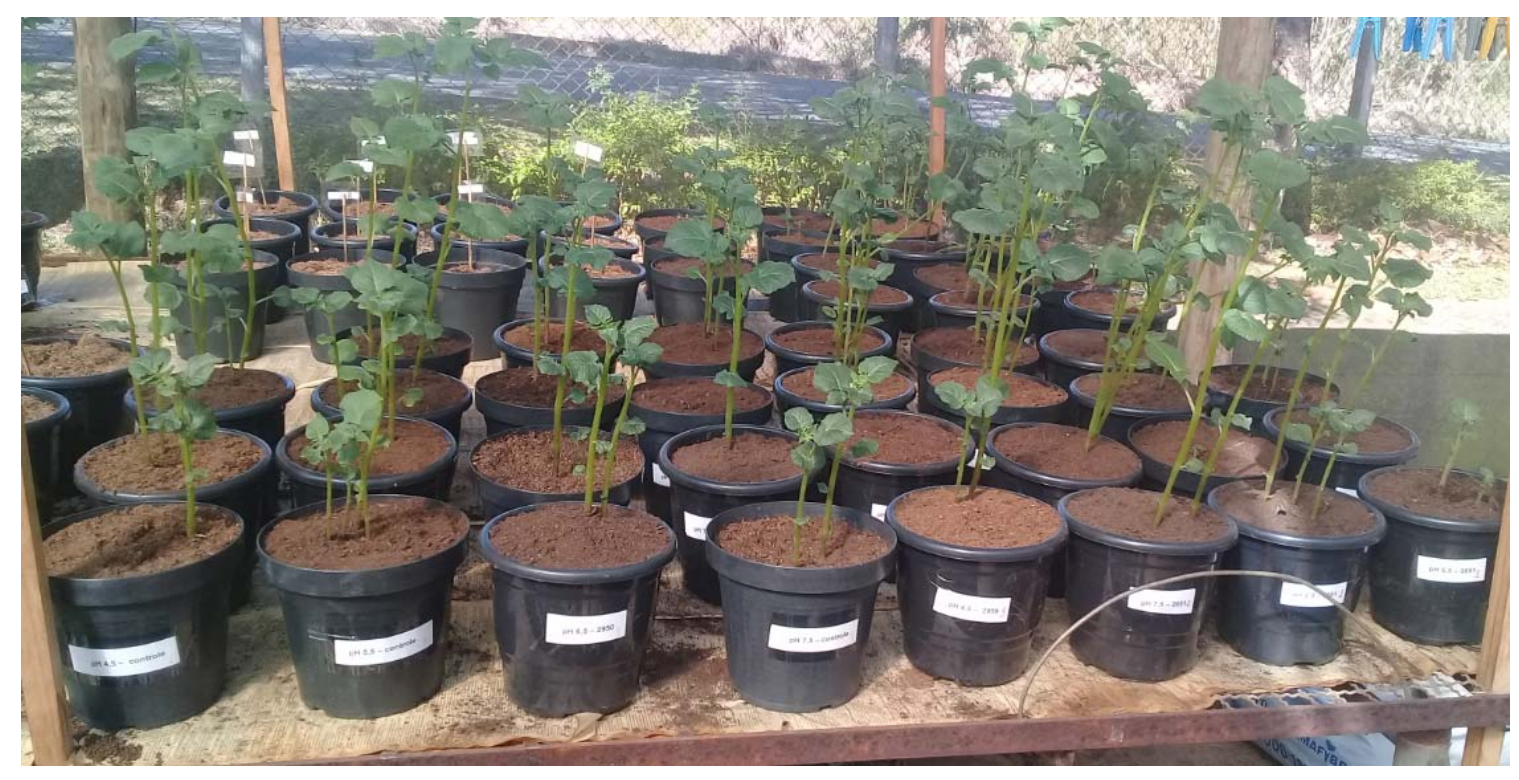

Figura 3. Plantas, aos 45 dias de plantio, mantidas na casa de vegetação. Fonte: LBV. 
Após aproximadamente 90 dias, com a senescência da planta, foi realizada a colheita para avaliação da incidência e severidade da doença e pesagem dos tubérculos. O percentual de área coberta pelas lesões foi determinado segundo a escala diagramática de James (1971), avaliando apenas a parte de cima do tubérculo, variando de 1 a 50\% (Figura 4). Para análise estatística foram atribuídas notas de acordo com a porcentagem dos sintomas, $0 \%$ - nota 0 ; $1 \%$ - nota $1 ; 10 \%$ - nota $2 ; 25 \%$ - nota 3 e $50 \%$ - nota 4 . Para avaliação dos sintomas da doença, somente os tubérculos maiores que $0,5 \mathrm{~cm}$ de diâmetro foram avaliados e classificados por severidade das lesões de sarna e percentual de área coberta por lesões. A escala de severidade da lesão utilizada foi: $0=$ sem lesões, $1=$ lesões superficiais $<10 \mathrm{~mm}$ de diâmetro, 2 = lesões superficiais $>10 \mathrm{~mm}$ de diâmetro, $3=$ lesões elevadas $<10 \mathrm{~mm}$ de diâmetro, 4 = lesões elevadas $>10 \mathrm{~mm}$ de diâmetro, 5 = lesões profundas (WANNER, 2007).

A produtividade de batata foi avaliada de acordo com diferentes tratamentos por meio das pesagens dos todos os tubérculos produzidos.

$\mathrm{O}$ delineamento experimental para o teste do $\mathrm{pH}$ foi o de blocos casualizados disposto em esquema fatorial 5 (pHs) x 2 (com e sem patógeno), com 5 repetições, sendo utilizado substratos com pH 4,0; 4,5; 5,5; 6,5; 7,5; com e sem adição do patógeno (controle). Um vaso individual contendo uma planta de batata representou uma unidade experimental.

Os dados foram submetidos à análise de variância (ANOVA) e as médias comparadas pelo teste de Tukey com nível de significância de 5\%. Para análise estatística, os dados foram transformados com $\sqrt{ } \mathrm{x}+0,5$. As análises foram realizadas com o software SISVAR versão 5.3 para Windows (Statistical Analysis Software, UFLA, Lavras, MG, BRA). 

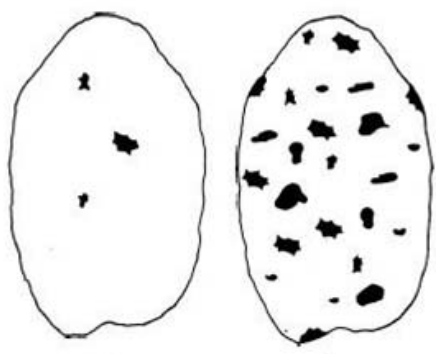

10

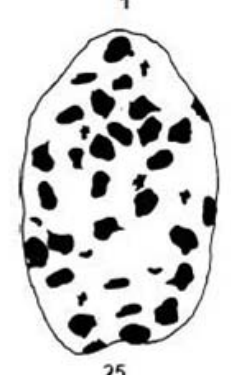

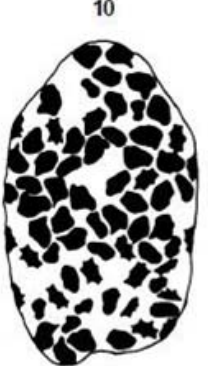

Figura 4. Escala diagramática para avaliação de percentual de área do tubérculo coberta pelas lesões de sarna. Fonte: Modificado de James (1971).

Porcentagem de área do tubérculo coberta por lesões.

4.4. Avaliação in vivo (casa de vegetação) da incidência e severidade da sarna da batata em diferentes regimes de irrigação do substrato inoculado com Streptomyces spp.

Os testes foram realizados em casa de vegetação, avaliando-se três regimes de irrigação do substrato: diariamente, em dias alternados (controle do teste) e uma vez por semana. Foram utilizadas as linhagens de S. acidiscabies IBSBF $2110^{\mathbf{T}}$, S. scabiei IBSBF

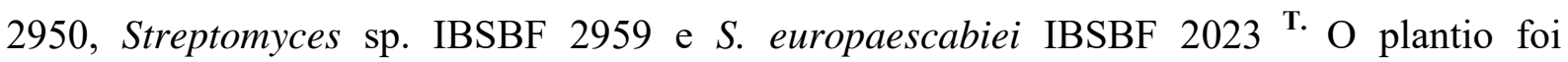
realizado de março a agosto de 2018 utilizando-se a variedade Ágata.

O procedimento de inoculação da bactéria no substrato foi o mesmo descrito no item 4.3. Nesse experimento foi utilizado o substrato de fibra de coco, Golden Mix Misto (Amafibra).

A irrigação foi realizada adicionando-se $100 \mathrm{~mL}$ de água em cada vaso por três vezes na semana até os 45 dias da data do plantio. Após essa data e com o início da tuberização, a irrigação foi efetuada de forma diferenciada de acordo com os regimes determinados. Como controle negativo foram utilizados vasos sem adição do inóculo. Após a senescência das plantas foi realizada a colheita dos tubérculos e avaliação da incidência e da severidade da doença de acordo com o descrito no item 4.3.

O delineamento experimental foi o de blocos casualizados disposto em esquema fatorial 3 (regimes de irrigação) x 2 (com e sem o patógeno), com 5 repetições, onde os 
tratamentos consistiram em irrigação 1 vez na semana, 3 vezes na semana e diariamente, e com e sem o patógeno (controle). Um vaso individual contendo uma planta de batata representou uma unidade experimental.

Os dados foram submetidos à análise de variância (ANOVA) e as médias comparadas pelo teste de Tukey com nível de significância de 5\%. Para análise estatística, os dados foram transformados com $\sqrt{ } \mathrm{x}+0,5$. As análises foram realizadas com o software SISVAR versão 5.3 para Windows (Statistical Analysis Software, UFLA, Lavras, MG, BRA). 


\section{RESULTADOS E DISCUSSÃO}

\subsection{Avaliação in vitro do crescimento de Streptomyces spp. em diferentes valores de pH do meio de cultivo}

Para os diferentes valores de $\mathrm{pH}$ do meio de cultivo testados foi possível observar crescimento bacteriano aos sete e 14 dias para quase a totalidade das linhagens (Tabela 4,

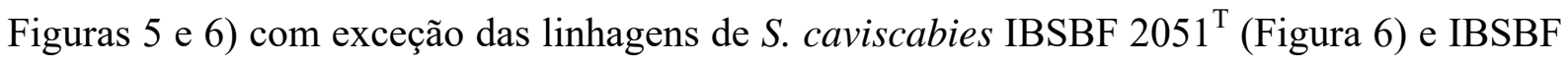
2400 que não apresentaram crescimento em pH 4,0 aos sete dias; somente a linhagem IBSBF $2051^{\mathrm{T}}$ mostrou ausência de crescimento aos 14 dias.

A linhagem de S. acidiscabies IBSBF $2110^{\mathrm{T}}$ foi utilizada como controle de crescimento bacteriano em $\mathrm{pH}$ ácidos, uma vez que a mesma foi descrita como tolerante ao $\mathrm{pH}$ 3,8 em testes in vitro (LAMBERT; LORIA, 1989a). Observando-se a Tabela 4 foi possível verificar que o comportamento das outras espécies de Streptomyces testadas foi muito similar ao da linhagem considerada controle.

De acordo com Lambert e Loria (1989b), a linhagem tipo da espécie de S. scabiei apresentou início de crescimento in vitro a partir do $\mathrm{pH} 5,0$. Entretanto, a linhagem de $S$. scabiei IBSBF 2950, de origem brasileira, apresentou crescimento em pH 4,0, demonstrando a diversidade genética entre linhagens desta mesma espécie.

Neste experimento foi verificado também que algumas linhagens apresentaram capacidade de alterar o $\mathrm{pH}$ do meio de cultivo, pois as medições ao final dos experimentos indicaram alteração dos diferentes $\mathrm{pH}$ para aproximadamente 6,5 (dados não publicados).

Dessa forma, não podemos afirmar que o $\mathrm{pH}$ representou um fator limitante para o crescimento da bactéria no meio de cultivo para a maioria das espécies estudadas. 
Tabela 4. Média do halo de crescimento (cm) de linhagens de Streptomyces spp. aos sete e 14 dias (d) após inoculação.

\begin{tabular}{|c|c|c|c|c|c|c|c|c|c|c|c|c|c|c|}
\hline \multirow{2}{*}{ Linhagens } & \multicolumn{2}{|c|}{ pH 4,0 } & \multicolumn{2}{|c|}{ pH 4,5 } & \multicolumn{2}{|c|}{ pH 5,0 } & \multicolumn{2}{|c|}{ pH 6,0 } & \multicolumn{2}{|c|}{ pH 7,0 } & \multicolumn{2}{|c|}{ pH 8,0 } & \multicolumn{2}{|c|}{ pH 9,0 } \\
\hline & $7 \mathrm{~d}$ & $14 \mathrm{~d}$ & $7 \mathrm{~d}$ & $14 \mathrm{~d}$ & $7 \mathrm{~d}$ & $14 \mathrm{~d}$ & $7 \mathrm{~d}$ & $14 \mathrm{~d}$ & $7 \mathrm{~d}$ & $14 \mathrm{~d}$ & $7 \mathrm{~d}$ & $14 \mathrm{~d}$ & $7 \mathrm{~d}$ & $14 \mathrm{~d}$ \\
\hline $\begin{array}{c}\text { S. caviscabies } \\
2400\end{array}$ & 0 & 1,53 & 1,70 & 3,30 & 1,60 & 3,03 & 1,73 & 3,07 & 1,80 & 3,00 & 1,13 & 3,10 & 1,77 & 3,23 \\
\hline $\begin{array}{l}\text { S.acidiscabies } \\
{ }^{*} 2110^{\mathrm{T}}\end{array}$ & 0,80 & 2,03 & 0,93 & 2,67 & 1,37 & 3,37 & 1,93 & 3,93 & 2,20 & 4,33 & 1,53 & 4,50 & 2,37 & 4,30 \\
\hline $\begin{array}{c}\text { S.europaescabiei } \\
2^{\mathrm{T}} \mathrm{T}^{\mathrm{T}}\end{array}$ & 0,57 & 2,37 & 1,90 & 3,77 & 1,77 & 3,53 & 1,90 & 3,67 & 1,87 & 3,40 & 1,17 & 3,33 & 1,73 & 3,03 \\
\hline $\begin{array}{c}\text { S. scabiei } \\
2950\end{array}$ & 0,80 & 2,83 & 1,70 & 3,63 & 1,97 & 3,90 & 1,93 & 4,03 & 2,07 & 4,03 & 1,27 & 3,83 & 1,77 & 3,53 \\
\hline $\begin{array}{c}\text { Streptomyces sp. } \\
2959\end{array}$ & 0,60 & 2,40 & 1,73 & 4,13 & 2,20 & 3,97 & 1,83 & 3,63 & 1,83 & 3,10 & 1,00 & 3,03 & 1,63 & 3,13 \\
\hline $\begin{array}{l}\text { S. caviscabies } \\
2^{2051}{ }^{\mathrm{T}}\end{array}$ & 0 & 0 & 0,53 & 1,20 & 1,23 & 2,17 & 1,47 & 2,63 & 1,73 & 2,77 & 0,97 & 2,70 & 1,73 & 2,53 \\
\hline
\end{tabular}

*S. acidiscabieis IBSBF $2110^{\mathrm{T}}$ - linhagem utilizada como controle de crescimento bacteriano em $\mathrm{pH}$ ácidos. 


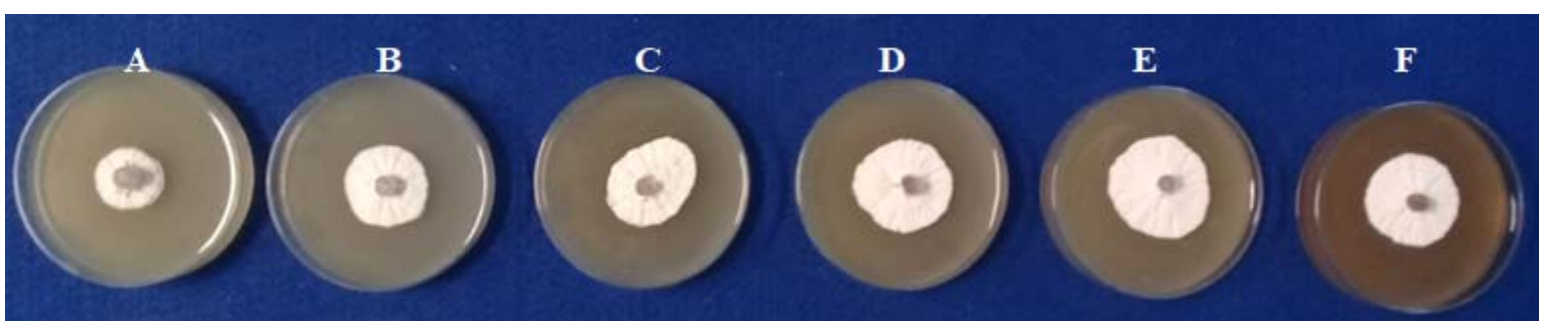

Figura 5. Teste de crescimento bacteriano in vitro com a linhagem de S. acidiscabieis (IBSBF $2110^{\mathrm{T}}$ ) aos 14 dias em diferentes valores de pH (A) 4,0; (B) 4,5; (C) 5,0; (D) 6,0; (E) 7,0; (F) 8,0 e (G) 9,0. Fonte: LBV

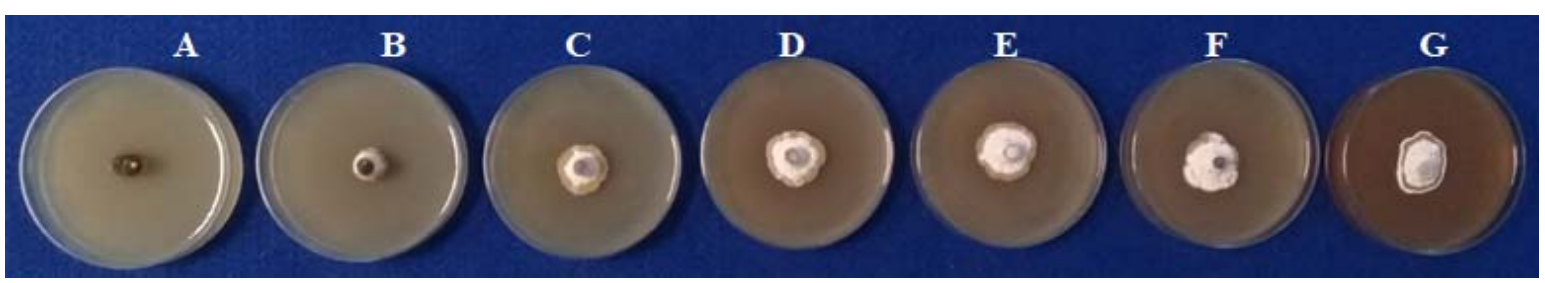

Figura 6. Teste de crescimento bacteriano in vitro com a linhagem de $S$. caviscabies (IBSBF $2051^{\mathrm{T}}$ ) aos 14 dias em diferentes valores de pH (A) 4,0; (B) 4,5; (C) 5,0; (D) 6,0; (E) 7,0; (F) 8,0 e (G) 9,0. Fonte: LBV

\subsection{Avaliação in vivo (casa de vegetação) da incidência e severidade da sarna da batata em diferentes valores de $\mathrm{pH}$ de substratos inoculados com Streptomyces spp.}

Os diferentes valores de $\mathrm{pH}$ dos substratos foram verificados no decorrer do experimento, no dia do plantio, após 45 dias e no dia da colheita, observando-se variação de no máximo 0,5 no valor do $\mathrm{pH}$ (Tabela 5). A medida do $\mathrm{pH}$ dos substratos durante o experimento foi realizada pelo método de Pour Through (LEBUDE; BILDERBACK, 2009).

Nos testes com os diferentes valores de $\mathrm{pH}$ dos substratos foi verificado um atraso na germinação e no desenvolvimento das plantas nos tratamentos de $\mathrm{pH} 4,0$, observando-se sintomas de nanismo e clorose (Figura 7) (dados não publicados). No tratamento com o pH 4,5 não houve produção de tubérculos em todas as repetições efetuadas com a linhagem IBSBF 2950. De acordo com Tabaldi e colaboradores (2007), em pH ácidos a menor disponibilidade de nutrientes é menor, além de uma redução na taxa de crescimento das raízes e parte aérea em função do aumento nos níveis de alumínio na solução do solo. 
Tabela 5. Medidas dos $\mathrm{pH}$ dos substratos realizadas durante o desenvolvimento da planta com aferição feita pelo método de Pour Through (LEBUDE; BILDERBACK, 2009).

\begin{tabular}{cccc}
\hline $\mathbf{p H}$ & Plantio & 45 dias após o plantio & Colheita \\
\hline 4,0 & 3,64 & 3,27 & 3,76 \\
4,5 & 4,13 & 4,24 & 4,01 \\
5,5 & 5,20 & 4,51 & 4,78 \\
6,5 & 6,45 & 6,08 & 6,12 \\
7,5 & 7,28 & 7,34 & 7,61 \\
\hline
\end{tabular}

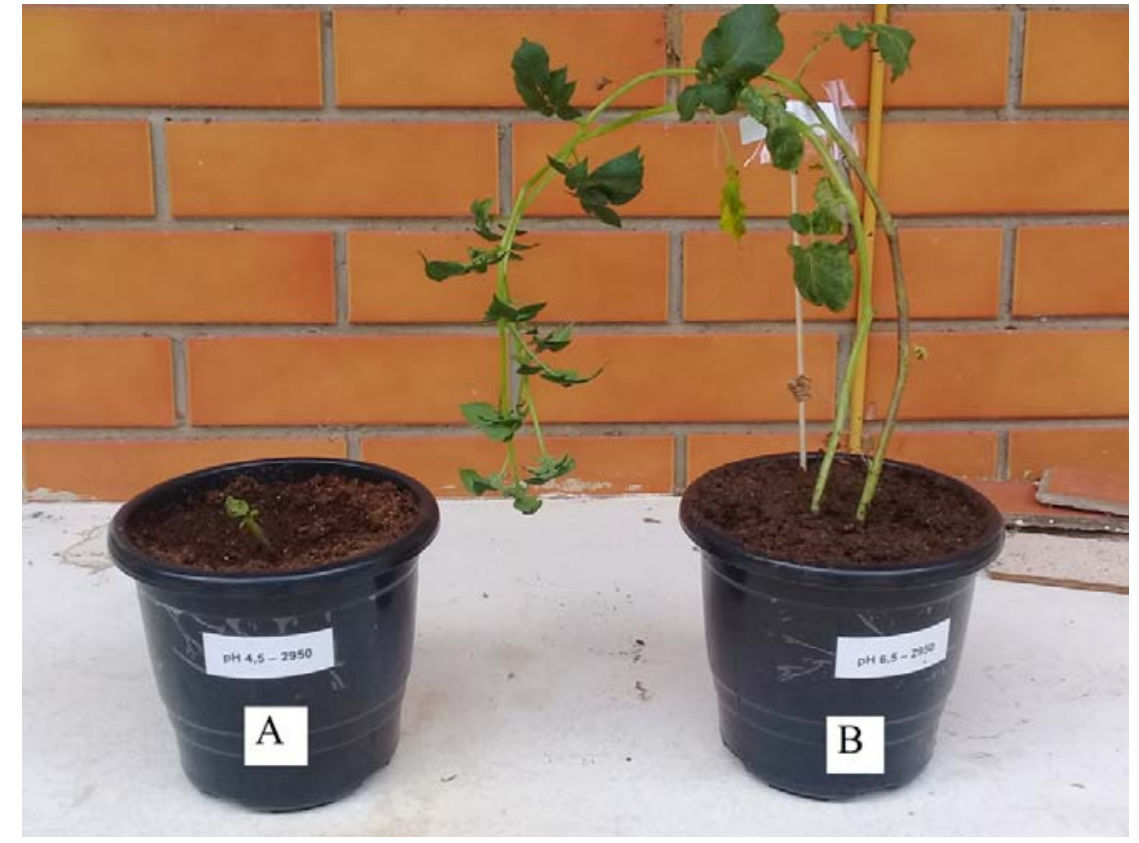

Figura 7. Plantas aos 45 dias de crescimento. (A) $\mathrm{pH} \mathrm{4,0} \mathrm{apresentando} \mathrm{nanismo} \mathrm{e} \mathrm{clorose} \mathrm{e} \mathrm{(B)} \mathrm{pH} 6,5$ planta em desenvolvimento considerado normal. Fonte: LBV

\subsubsection{Incidência e severidade da sarna da batata}

Avaliando-se os experimentos em diferentes valores de $\mathrm{pH}$ dos substratos verificou-se que as maiores notas de incidência da sarna foram observadas nos $\mathrm{pH}$ 7,5 e 6,5 para todas as espécies de Streptomyces testadas. Os tratamentos no $\mathrm{pH}$ 4,0 resultaram na supressão da doença nos testes com as espécies de S. scabiei, Streptomyces sp. e S. caviscabies, apenas a espécie de $S$. acidiscabies apresentou algumas parcelas com sintomas. No pH 4,5 observou-se uma menor incidência da sarna da batata quando comparado aos tratamentos com valores maiores de $\mathrm{pH}$, com exceção da espécie $S$. acidiscabies que apresentou elevados índices da doença (Figura 8). 


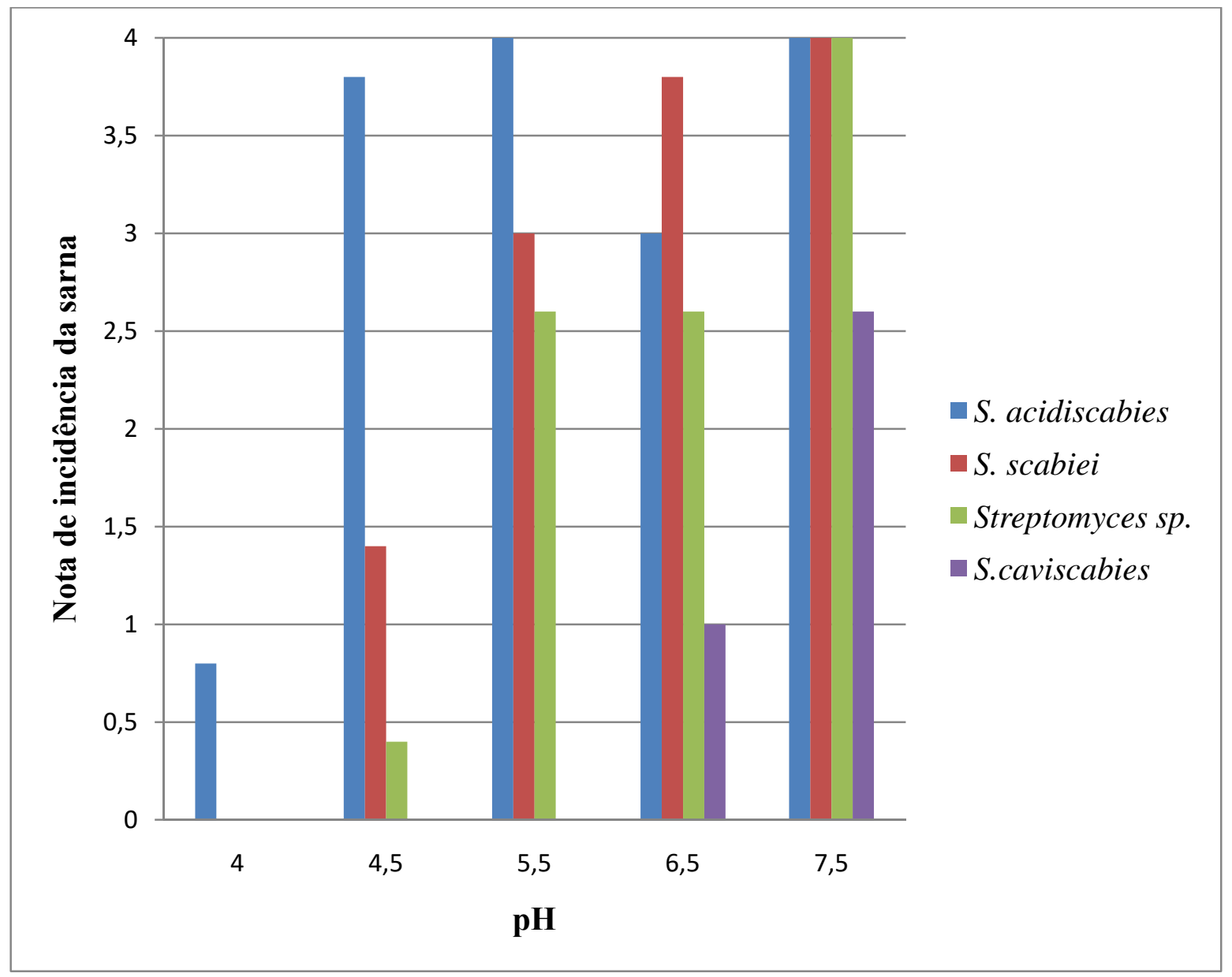

Figura 8. Notas de incidência da sarna da batata em diferentes valores de $\mathrm{pH}$ dos substratos atribuídas aos sintomas causados pelas diferentes espécies de Streptomyces no período do inverno.

As espécies de S. acidiscabies e S. scabiei foram testadas nas duas estações do ano verão e inverno (Figuras 9A e 9B), com o objetivo de se verificar o comportamento das espécies com relação à temperatura. Nestes experimentos, observou-se que no $\mathrm{pH} 4,0$ a supressão da doença foi mantida nas duas épocas testadas. Também foi possível verificar uma maior supressão da doença nos pH 4,5 e 5,5 durante o verão, não se mantendo durante a safra de inverno. De acordo com Dees and Wanner (2012), a incidência e a severidade da doença podem variar de local para local e de ano para ano em uma mesma região. Os dados aqui apresentados demonstraram a grande versatilidade de desenvolvimento da bactéria às diferentes condições ambientais e climáticas, entre outros fatores; dificultando ainda mais o manejo da doença. 


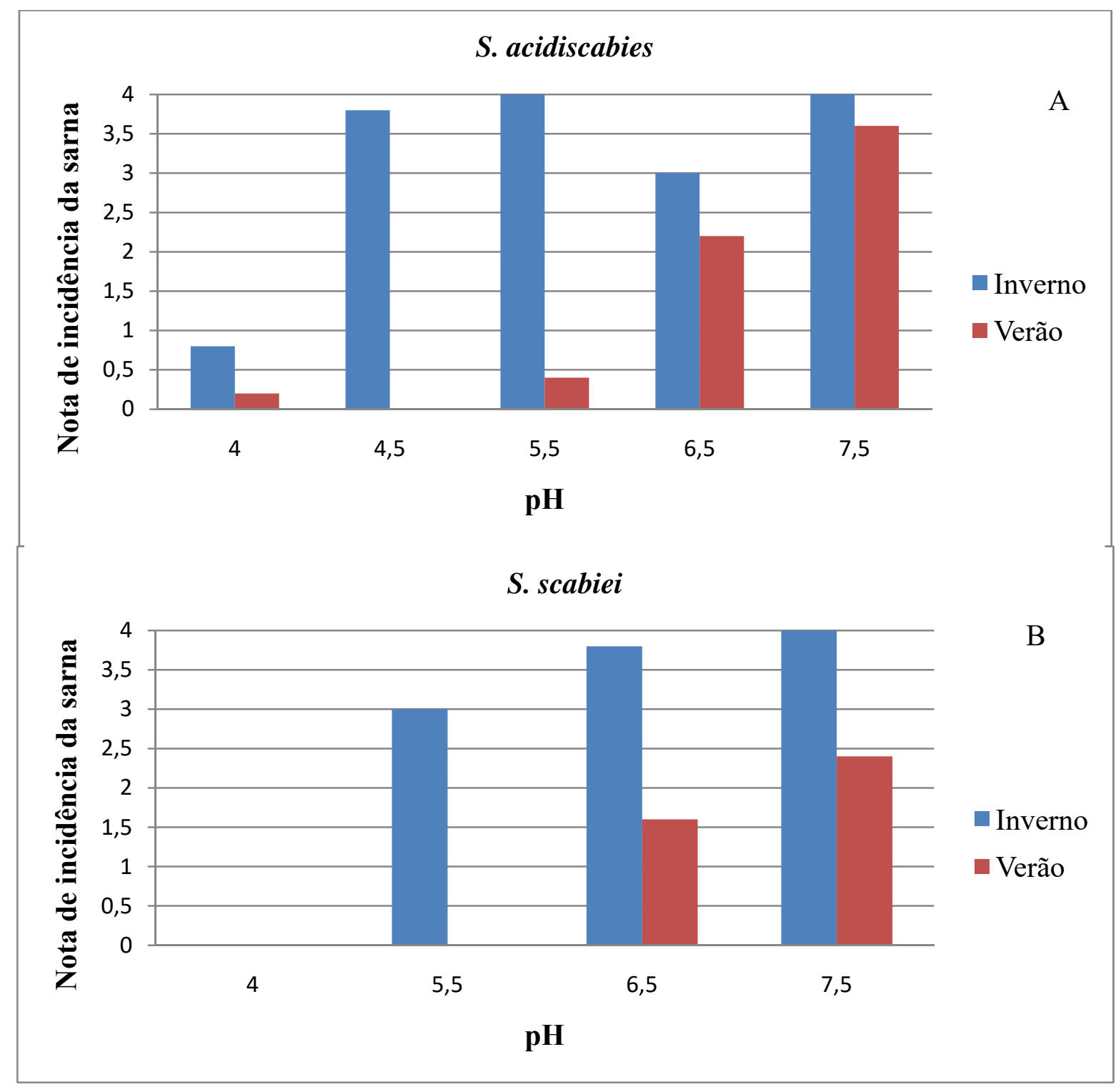

Figura 9. Notas de incidência da sarna da batata em diferentes pH dos substratos atribuídas às espécies de $S$. scabiei (A) e S. acidiscabies (B) nas estações de inverno e verão.

As análises de variância em diferentes valores de $\mathrm{pH}$ dos substratos inoculados com as espécies de S. acidiscabieis, S. scabiei, Streptomyces sp. e S. caviscabies (Tabelas 6, 7, 8 e 9) mostraram diferenças significativas entre os tratamentos $(\mathrm{P}<0,05)$ (dados transformados).No teste realizado no inverno para a linhagem $S$. acidiscabies, as maiores notas de incidência foram verificadas no $\mathrm{pH}$ 7,5 e 5,5 com nota média de 2,50; enquanto que no $\mathrm{pH}$ 4,5 a nota foi de 2,44 e no pH 6,5, de 2,19; não sendo observadas diferenças significativas entre os tratamentos (Figura 10). O pH 4,0 foi o que apresentou o menor índice da doença com nota média de 1,04 se diferenciando estatisticamente dos outros valores de $\mathrm{pH}$ do substrato. Todos os tratamentos apresentaram diferenças significativas quando comparados com e sem a 
inoculação do patógeno. Com relação à severidade da doença, a menor média foi obtida no $\mathrm{pH} 4,0$, se diferenciando estatisticamente dos outros tratamentos que apresentaram maiores valores de severidade da doença (Tabela 6).

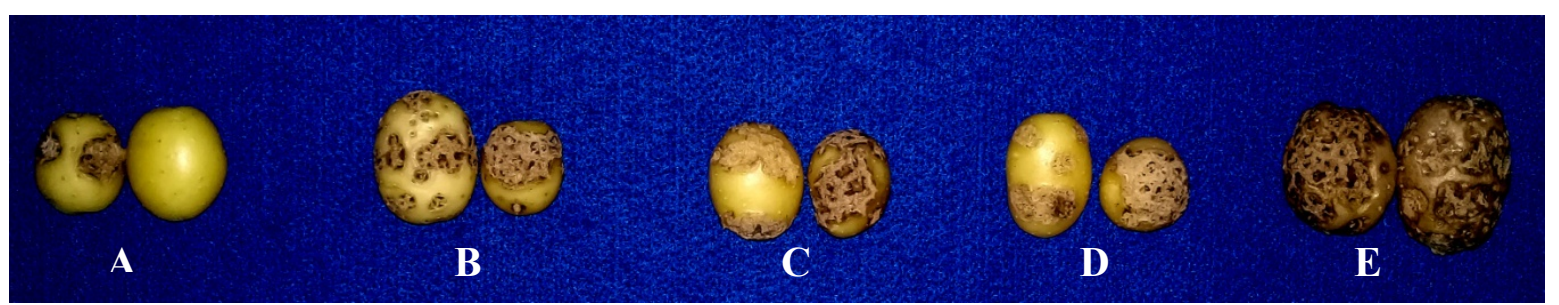

Figura 10. Tubérculos colhidos a partir dos substratos inoculados com a linhagem de $S$. acidiscabies IBSBF $2110^{\mathrm{T}}$ em diferentes valores de $\mathrm{pH}$ (A) 4,0; (B) 4,5; (C) 5,5; (D) 6,5 e (E) 7,5. Fonte: LBV

Nos experimentos realizados no verão com a linhagem de $S$. acidiscabies (Tabela 6), a maior incidência da doença foi verificada nos substratos de $\mathrm{pH}$ 7,5 e $\mathrm{pH}$ 6,5 com notas de sintomas (média) de 2,38 e 1,97 respectivamente, que por sua vez foram maiores significativamente que aquelas dos demais $\mathrm{pH}$, que não diferiram entre si. No que se refere aos tratamentos com e sem inoculação da bactéria verificou-se diferenças significativas somente para os $\mathrm{pH} 5,5 ; 6,5$ e 7,5; sendo que os tratamentos inoculados apresentaram os maiores valores observados.

Com relação à severidade da doença nesse período, as maiores médias foram alcançadas no pH 7,5 e 6,5 que não se diferenciaram entre si, se diferenciando apenas dos outros tratamentos. No que se refere aos tratamentos com e sem inoculação, verificou-se diferenças significativas somente para os $\mathrm{pH}$ 6,5 e 7,5, sendo que os tratamentos inoculados apresentaram os maiores valores observados.

A espécie de S. acidiscabies foi descrita em solos com pH menores que 5,2; tolerando pH de 3,8 em testes in vitro (LAMBERT; LORIA, 1989a). Dessa forma, a espécie tolera e se desenvolve em solos ácidos. Esse dado foi constatado pelo presente estudo onde, das espécies estudadas, a linhagem de S. acidiscabies foi a única que apresentou sintomas da doença em substrato com pH 4,0. Entretanto, nosso estudo mostrou também que essa espécie bacteriana apresentou agressividade em todos os valores de $\mathrm{pH}$ testados com exceção do $\mathrm{pH} 4,0$, demonstrando sua capacidade patogênica de desenvolvimento em ampla faixa de $\mathrm{pH}$ (Tabela $6)$. 
Tabela 6. Valores das médias das notas da incidência e severidade da sarna da batata em diferentes valores de $\mathrm{pH}$ dos substratos inoculados ou não com a linhagem de $S$. acidiscabies IBSBF $2110^{\mathrm{T}}$.

\begin{tabular}{|c|c|c|c|c|}
\hline \multicolumn{5}{|c|}{ Incidência da doença } \\
\hline & \multicolumn{2}{|c|}{ Inverno } & \multicolumn{2}{|c|}{ Verão } \\
\hline pH substrato & CI & SI & CI & SI \\
\hline 4 & $1,04 \mathrm{~B} \mathrm{a}$ & $0,50 \mathrm{~A} \mathrm{~b}$ & $0,70 \mathrm{~B}$ a & $0,50 \mathrm{~A} \mathrm{a}$ \\
\hline 4,5 & $2,44 \mathrm{~A} \mathrm{a}$ & $0,50 \mathrm{~A} \mathrm{~b}$ & $0,50 \mathrm{~B}$ a & $0,50 \mathrm{~A} \mathrm{a}$ \\
\hline 5,5 & $2,50 \mathrm{~A} \mathrm{a}$ & $0,50 \mathrm{~A} \mathrm{~b}$ & $0,90 \mathrm{~B} \mathrm{a}$ & $0,50 \mathrm{~A} \mathrm{~b}$ \\
\hline 6,5 & $2,19 \mathrm{~A}$ a & $0,50 \mathrm{~A} \mathrm{~b}$ & $1,97 \mathrm{~A} \mathrm{a}$ & $0,50 \mathrm{~A} \mathrm{~b}$ \\
\hline 7,5 & $2,50 \mathrm{~A} \mathrm{a}$ & $0,50 \mathrm{~A} \mathrm{~b}$ & $2,38 \mathrm{~A} \mathrm{a}$ & $0,50 \mathrm{~A} \mathrm{~b}$ \\
\hline $\mathrm{CV} \%$ & \multicolumn{2}{|c|}{21,56} & \multicolumn{2}{|c|}{27,12} \\
\hline \multicolumn{5}{|c|}{ Severidade da doença } \\
\hline & \multicolumn{2}{|c|}{ Inverno } & \multicolumn{2}{|c|}{ Verão } \\
\hline pH substrato & CI & SI & CI & SI \\
\hline 4 & $1,29 \mathrm{~B}$ a & $0,50 \mathrm{~A} \mathrm{~b}$ & $0,84 \mathrm{~B} \mathrm{a}$ & $0,50 \mathrm{~A} a$ \\
\hline 4,5 & $2,32 \mathrm{~A}$ a & $0,50 \mathrm{~A} \mathrm{~b}$ & $0,5 \mathrm{~B} \mathrm{a}$ & $0,50 \mathrm{~A} \mathrm{a}$ \\
\hline 5,5 & $2,28 \mathrm{~A} \mathrm{a}$ & $0,50 \mathrm{~A} \mathrm{~b}$ & $0,9 \mathrm{~B} \mathrm{a}$ & $0,5 \mathrm{~A} a$ \\
\hline 6,5 & $2,20 \mathrm{~A} \mathrm{a}$ & $0,50 \mathrm{~A} \mathrm{~b}$ & $1,84 \mathrm{~A} \mathrm{a}$ & $0,50 \mathrm{~A} \mathrm{~b}$ \\
\hline 7,5 & $2,33 \mathrm{~A} \mathrm{a}$ & $0,50 \mathrm{~A} \mathrm{~b}$ & $1,84 \mathrm{~A} \mathrm{a}$ & $0,50 \mathrm{~A} \mathrm{~b}$ \\
\hline $\mathrm{CV} \%$ & \multicolumn{2}{|c|}{29,89} & \multicolumn{2}{|c|}{43,8} \\
\hline
\end{tabular}

*Médias seguidas da mesma letra maiúscula na coluna e minúscula na linha não diferem entre si pelo teste de Tukey (P<0,05). (CI) Com inoculação; (SI) Sem inoculação.

Nos testes realizados com a espécie de S. scabiei na safra de inverno, verificou-se que no substrato de $\mathrm{pH}$ 4,0 com inoculação da bactéria não foi observada incidência da doença se igualando ao tratamento controle (nota 0,5 ). No pH 4,5 verificou-se uma menor incidência da doença com nota média dos sintomas de 1,5; se diferenciando estatisticamente das maiores médias obtidas pelos pH 5,5 (nota 2,21); 6,5 (nota 2,44) e 7,5 (nota 2,50) (Figura 11) que não apresentaram diferenças estatísticas entre si. Com relação à severidade da doença não foi observado sintomas de sarna nos tubérculos plantados no substrato com pH 4,0 conforme já mencionado, este então se diferenciou estatisticamente de todos os outros $\mathrm{pH}$ do substrato que apresentaram maiores médias de severidade, sendo o único dos tratamentos que não apresentou diferenças com e sem a inoculação da bactéria (Tabela 7). 
Tabela 7. Valores das médias das notas da incidência e severidade da sarna da batata em diferentes valores de $\mathrm{pH}$ dos substratos inoculados ou não com a linhagem de S. scabiei IBSBF 2950.

\begin{tabular}{|c|c|c|c|c|}
\hline \multicolumn{5}{|c|}{ Incidência da doença } \\
\hline \multirow[b]{2}{*}{ pH substrato } & \multicolumn{2}{|c|}{ Inverno } & \multicolumn{2}{|c|}{ Verão } \\
\hline & \multicolumn{2}{|c|}{ 1714 } & CI & SI \\
\hline 4 & $0,50 \mathrm{C} \mathrm{a}$ & $0,50 \mathrm{~A} \mathrm{a}$ & $0,50 \mathrm{C} \mathrm{a}$ & $0,50 \mathrm{~A} \mathrm{a}$ \\
\hline 4,5 & $1,55 \mathrm{~B}$ a & $0,50 \mathrm{~A} \mathrm{~b}$ & & \\
\hline 5,5 & $2,21 \mathrm{~A} \mathrm{a}$ & $0,50 \mathrm{~A} \mathrm{~b}$ & $0,50 \mathrm{C} \mathrm{a}$ & $0,50 \mathrm{~A} \mathrm{a}$ \\
\hline 6,5 & $2,44 \mathrm{~A}$ a & $0,50 \mathrm{~A} \mathrm{~b}$ & $1,73 \mathrm{~B} \mathrm{a}$ & $0,50 \mathrm{~A} \mathrm{~b}$ \\
\hline 7,5 & $2,50 \mathrm{~A} \mathrm{a}$ & $0,50 \mathrm{~A} \mathrm{~b}$ & $2,13 \mathrm{~A} \mathrm{a}$ & $0,50 \mathrm{~A} \mathrm{~b}$ \\
\hline \multirow[t]{3}{*}{$\mathrm{CV} \%$} & \multicolumn{2}{|c|}{18,63} & \multicolumn{2}{|c|}{22,31} \\
\hline & \multicolumn{3}{|c|}{ Severidade da doença } & \\
\hline & \multicolumn{2}{|c|}{ Inverno } & \multicolumn{2}{|c|}{ Verão } \\
\hline pH substrato & CI & SI & CI & SI \\
\hline 4 & $0,50 \mathrm{~B}$ a & $0,50 \mathrm{~A} \mathrm{a}$ & \multirow[t]{2}{*}{$0,50 \mathrm{~B} \mathrm{a}$} & \multirow[t]{2}{*}{$0,50 \mathrm{~A} \mathrm{a}$} \\
\hline 4,5 & $2,14 \mathrm{~A} \mathrm{a}$ & $0,50 \mathrm{~A} \mathrm{~b}$ & & \\
\hline 5,5 & $2,59 \mathrm{~A} \mathrm{a}$ & $0,50 \mathrm{~A} \mathrm{~b}$ & $0,50 \mathrm{~B}$ a & $0,50 \mathrm{~A} \mathrm{a}$ \\
\hline 6,5 & $2,64 \mathrm{~A} \mathrm{a}$ & $0,50 \mathrm{~A} \mathrm{~b}$ & $2,05 \mathrm{~A} \mathrm{a}$ & $0,50 \mathrm{~A} \mathrm{~b}$ \\
\hline 7,5 & $2,44 \mathrm{~A} \mathrm{a}$ & $0,50 \mathrm{~A} \mathrm{~b}$ & $2,19 \mathrm{~A} \mathrm{a}$ & $0,50 \mathrm{~A} \mathrm{~b}$ \\
\hline $\mathrm{CV} \%$ & \multicolumn{2}{|c|}{34,07} & \multicolumn{2}{|c|}{25,58} \\
\hline
\end{tabular}

*Médias seguidas da mesma letra maiúscula na coluna e minúscula na linha não diferem entre si pelo teste de Tukey $(\mathbf{P}<0,05)$. (CI) Com inoculação; (SI) Sem inoculação.

No verão, a maior incidência da doença nas inoculações com a linhagem de S. scabiei foi observada no substrato com $\mathrm{pH} 7,5$ com nota média de sintomas de 2,13; seguido pelo $\mathrm{pH}$ 6,5 (nota 1,73 ) e se diferenciando do $\mathrm{pH}$ 4,0 e 5,5 que não apresentaram sintomas da doença. Estes últimos, por sua vez, se igualaram estatisticamente aos tratamentos que não receberam inoculação da bactéria. Já no pH 6,5 e 7,5 foram verificadas diferenças significativas entre os tratamentos com e sem a inoculação do patógeno. Na severidade da doença, as maiores médias foram obtidas no $\mathrm{pH} 7,5$ (nota 2,19) e 6,5 (nota 2,05), que se diferenciaram dos $\mathrm{pH} 5,5$ e 4,5 que não apresentaram sintomas da doença nesse caso.

Solos com pH menores que 5,2 são considerados geralmente supressivos para sarna causada por S. scabiei (Waksman, 1921; Powelson et al., 1993). Esses resultados também foram constatados em estudos com a espécie S. scabiei na região da Austrália por Lacey e Wilson (2001) onde 9 das 10 amostras testadas não apresentaram a doença quando o $\mathrm{pH}$ do solo se apresentava com valores menores que 5,0; e nosso estudo corroborou esses relatos.. 


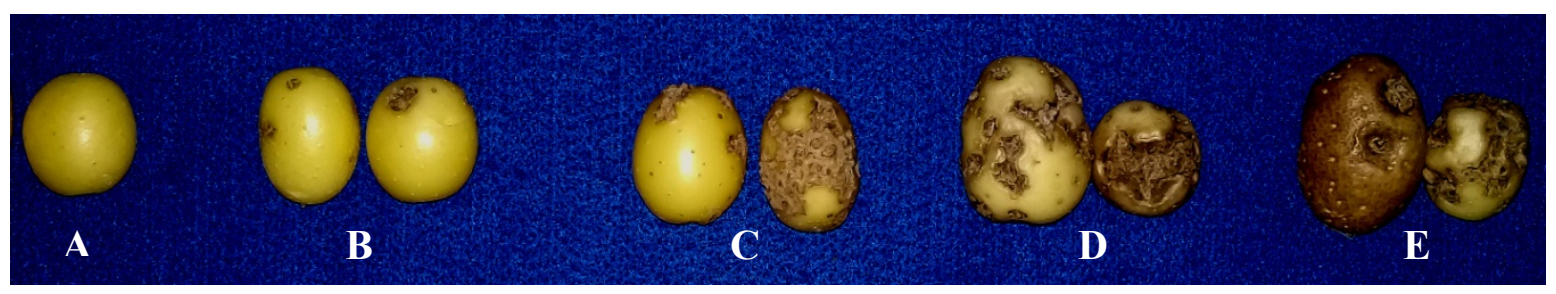

Figura 11. Tubérculos colhidos a partir dos substratos inoculados com a linhagem de $S$. scabiei IBSBF $2950 \mathrm{em}$ diferentes valores de $\mathrm{pH}$ (A) 4,0; (B) 4,5; (C) 5,5; (D) 6,5 e (E) 7,5. Fonte: LBV

Nos testes com a linhagem de Streptomyces sp. IBSBF 2959, a maior nota de incidência da doença foi observada no $\mathrm{pH}$ 7,5 (nota 2,5), se diferenciando estatisticamente dos $\mathrm{pH}$ 6,5 e 5,5 ambos com nota 2,1. Estes dois valores de $\mathrm{pH}(6,5$ e 7,5) por sua vez se diferenciaram dos substratos com $\mathrm{pH} 4,5$ (nota 0,9 ) e 4,0 (nota 0,5 ). No tratamento com $\mathrm{pH}$ 4,0 com adição da bactéria não foram observados sintomas da doença, sendo o único tratamento de comportamento similar ao controle ((Tabela 8, Figura 12).

Tabela 8. Valores das médias das notas da incidência e severidade da sarna da batata em diferentes valores de $\mathrm{pH}$ dos substratos inoculados ou não com a linhagem de Streptomyces sp. IBSBF 2959.

\begin{tabular}{|c|c|c|}
\hline \multicolumn{3}{|c|}{ Incidência da doença } \\
\hline pH substrato & CI & SI \\
\hline 4 & $0,50 \mathrm{D}$ a & $0,50 \mathrm{~A} \mathrm{a}$ \\
\hline 4,5 & $0,90 \mathrm{C} \mathrm{a}$ & $0,50 \mathrm{~A} \mathrm{~b}$ \\
\hline 5,5 & $2,10 \mathrm{~B}$ a & $0,50 \mathrm{~A} \mathrm{~b}$ \\
\hline 6,5 & $2,10 \mathrm{~B} \mathrm{a}$ & $0,50 \mathrm{~A} \mathrm{~b}$ \\
\hline 7,5 & $2,50 \mathrm{~A} \mathrm{a}$ & $0,50 \mathrm{~A} \mathrm{~b}$ \\
\hline $\mathrm{CV} \%$ & & \\
\hline \multicolumn{3}{|c|}{ Severidade da doença } \\
\hline pH substrato & CI & SI \\
\hline 4 & $0,50 \mathrm{C} \mathrm{a}$ & $0,50 \mathrm{~A} \mathrm{a}$ \\
\hline 4,5 & $0,98 \mathrm{~B}$ a & $0,50 \mathrm{~A} \mathrm{~b}$ \\
\hline 5,5 & $2,16 \mathrm{~A} \mathrm{a}$ & $0,50 \mathrm{~A} \mathrm{~b}$ \\
\hline 6,5 & $1,97 \mathrm{~A} \mathrm{a}$ & $0,50 \mathrm{~A} \mathrm{~b}$ \\
\hline 7,5 & $2,34 \mathrm{~A} a$ & $0,50 \mathrm{~A} \mathrm{~b}$ \\
\hline $\mathrm{CV} \%$ & \multicolumn{2}{|c|}{22,68} \\
\hline
\end{tabular}

*Médias seguidas da mesma letra maiúscula na coluna e minúscula na linha não diferem entre si pelo teste de Tukey $(\mathrm{P}<0,05)$. (CI) Com inoculação; (SI) Sem inoculação.

$\mathrm{Na}$ avaliação de severidade da doença para essa linhagem, as maiores médias foram obtidas nos substratos inoculados com a bactéria em pH 7,5 (nota 2,34); 5,5 (nota 2,16) e 6,5 
(nota 1,97), respectivamente, não sendo observada diferença significativa entre eles. O pH 4,5 com nota média de incidência da doença de 0,98 se diferenciou estatisticamente de todos os outros tratamento. Ainda, como observado nos dados de avaliação da incidência da doença, no $\mathrm{pH}$ 4,0 não foram observados sintomas de sarna, se igualando ao controle sem a inoculação da bactéria.

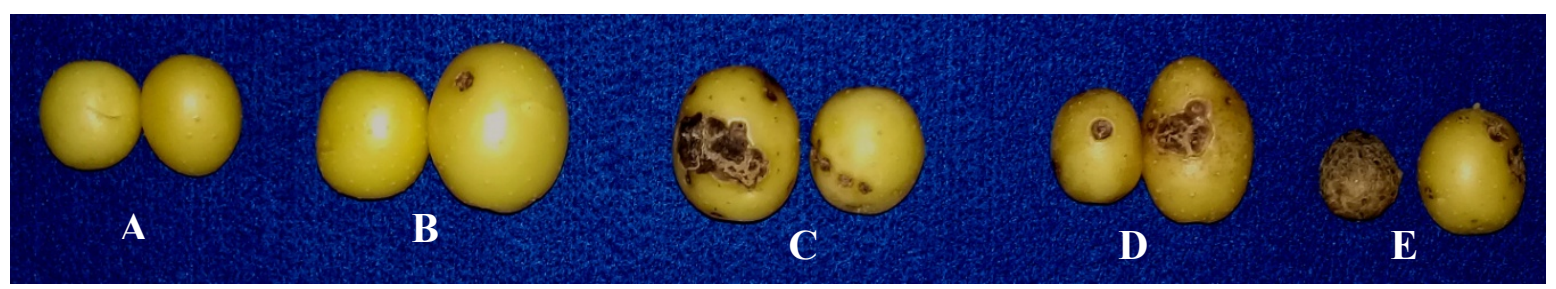

Figura 12. Tubérculos colhidos a partir dos substratos inoculados com a linhagem de Streptomyces sp. IBSBF 2959 em diferentes valores de $\mathrm{pH}$ (A) 4,0; (B) 4,5; (C) 5,5; (D) 6,5 e (E) 7,5.

Nos experimentos com a espécie de S. caviscabies (Tabela 9), observou-se incidência da doença apenas nos tratamentos com pH 7,5 (nota 2,06) e 6,5 (nota 1,13); com diferença significativa entre eles. O mesmo ocorreu nos resultados de nota de severidade da doença. Os dados mostraram que essa espécie bacteriana não tolera valores baixos de $\mathrm{pH}$, corroborando os resultados obtidos dos testes in vitro (Tabela 4), onde apenas a linhagem de S. caviscabies não apresentou crescimento no meio de cultivo com pH 4,0. Dessa forma, a manutenção do pH do solo em valores baixos (acidificação) pode vir a ser uma estratégia de manejo para solos contaminados com essa espécie bacteriana. 
Tabela 9. Valores das médias das notas da incidência e severidade da sarna da batata em diferentes valores de $\mathrm{pH}$ dos substratos inoculados ou não com a linhagem de $S$. caviscabies IBSBF $2051^{\mathrm{T}}$.

\begin{tabular}{|c|c|c|}
\hline \multicolumn{3}{|c|}{ Incidência da doença } \\
\hline pH substrato & CI & SI \\
\hline 4 & $0,50 \mathrm{C} \mathrm{a}$ & $0,50 \mathrm{~A} a$ \\
\hline 4,5 & $0,50 \mathrm{C} \mathrm{a}$ & $0,50 \mathrm{~A} \mathrm{a}$ \\
\hline 5,5 & $0,50 \mathrm{C} \mathrm{a}$ & $0,50 \mathrm{~A} \mathrm{a}$ \\
\hline 6,5 & $1,13 \mathrm{~B} \mathrm{a}$ & $0,50 \mathrm{~A} \mathrm{~b}$ \\
\hline 7,5 & $2,06 \mathrm{~A} \mathrm{a}$ & $0,50 \mathrm{~A} \mathrm{~b}$ \\
\hline $\mathrm{CV} \%$ & & \\
\hline \multicolumn{3}{|c|}{ Severidade da doença } \\
\hline pH substrato & CI & SI \\
\hline 4 & $0,50 \mathrm{C} \mathrm{a}$ & $0,50 \mathrm{~A} \mathrm{a}$ \\
\hline 4,5 & $0,50 \mathrm{C} \mathrm{a}$ & $0,50 \mathrm{~A} \mathrm{a}$ \\
\hline 5,5 & $0,50 \mathrm{C} \mathrm{a}$ & $0,50 \mathrm{~A} a$ \\
\hline 6,5 & $0,90 \mathrm{~B} \mathrm{a}$ & $0,50 \mathrm{~A} \mathrm{~b}$ \\
\hline 7,5 & $1,50 \mathrm{~A} \mathrm{a}$ & $0,50 \mathrm{~A} \mathrm{~b}$ \\
\hline
\end{tabular}

*Médias seguidas da mesma letra maiúscula na coluna e minúscula na linha não diferem entre si pelo teste de Tukey (P<0,05). (CI) Com inoculação; (SI) Sem inoculação.

Em linhas gerais, com esse estudo foi possível verificar que o $\mathrm{pH}$ do substrato pode interferir no desenvolvimento do patógeno responsável pela sarna da batata, onde os tratamentos com valores de $\mathrm{pH}$ acima de 5,5 apresentaram as maiores notas de incidência da doença. Esses resultados corroboram os obtidos por Lacey e Wilson (2001), mas contrastaram com os dados obtidos por Wiechel e Crump (2010), pois em avaliações, durante três anos na Austrália, os autores concluíram que a incidência da sarna da batata não está diretamente ligada ao $\mathrm{pH}$ do solo.

Ademais, os resultados obtidos neste trabalho representam a primeira constatação da clara interferência do pH do solo sobre linhagens de Streptomyces que ocorrem no Brasil.

Estudos futuros deverão ser realizados para se verificar a interferência dos nutrientes do solo na incidência da sarna da batata, levando-se em conta que o $\mathrm{pH}$ pode modificar a disponibilidade dos nutrientes para as plantas. Solos de baixo $\mathrm{pH}$ tendem a ter níveis mais elevados de manganês, confirmados com a análise nutricional (Tabela 3), onde a maior concentração desse nutriente foi observada no $\mathrm{pH} 4,0$, sendo este o que apresentou menor incidência e severidade da doença. Segundo relatos de Mcgregor e Wilson (1966), o 
manganês foi associado a uma redução na sarna da batata em alguns ensaios, mas este fato não foi confirmado por outros estudos.

\subsubsection{Produtividade dos tubérculos}

Este estudo também avaliou a produtividade dos tubérculos obtida nos experimentos com as espécies de Streptomyces nos diferentes valores de $\mathrm{pH}$ dos substratos (Tabela 10). Os resultados mostraram que as linhagens de Streptomyces testadas não interferiram na produção de tubérculos nas condições do estudo.

No caso dos testes efetuados na época do inverno com as espécies de S. acidiscabies, S. caviscabies e S. scabiei, a produção de tubérculos em substrato com $\mathrm{pH}$ 4,0 foi significativamente menor quando comparada com o tratamento sem inoculação do patógeno. Nos tratamentos com outros valores de $\mathrm{pH}$ não foram observadas diferenças significativas na produtividade entre ensaios com e sem a presença da fitobactéria.

Segundo Hiltunen e colaboradores (2005), infecções severas do patógeno podem comprometer a produtividade da cultura da batata. Entretanto, no presente estudo a presença da bactéria não afetou a produtividade, sendo que em alguns casos, os maiores valores de produtividade foram observados na presença do patógeno.

De acordo com a Tabela 10, para a espécie de S. acidiscabieis, na safra do inverno, a maior média de produtividade foi observada no $\mathrm{pH} 5,5(5,51 \mathrm{~g})$. Nos tratamentos sem a inoculação da bactéria, o pH 4,0 apresentou a menor média $(2,88 \mathrm{~g})$ se diferenciando estatisticamente dos outros tratamentos. No estudo realizado no verão para essa espécie bacteriana, o pH 4,0 também apresentou a menor média de produção de tubérculos $(2,39 \mathrm{~g})$. Com os substratos inoculados com S. scabiei no inverno, o cultivo em substrato com $\mathrm{pH} 5,5$ apresentou a maior média de produção de tubérculos com 5,43 g, se diferenciando apenas do tratamento com $\mathrm{pH}$ 7,5. Nos tratamentos controle, o substrato com $\mathrm{pH} 4,0$ apresentou a menor média de peso dos tubérculos, diferenciando-se dos outros tratamentos. 
Tabela 10. Valores das médias de produtividade dos tubérculos de batata em (gramas) em diferentes valores de $\mathrm{pH}$ inoculados ou não com as linhagens de Streptomyces spp.

\begin{tabular}{|c|c|c|c|}
\hline \multicolumn{4}{|c|}{ Produção de tubérculos (g) com S. acidiscabies } \\
\hline & \multicolumn{2}{|c|}{ Inverno } & Verão \\
\hline pH substrato & CI & SI & \\
\hline 4 & $4,48 \mathrm{AB}$ a & $2,88 \mathrm{~B} \mathrm{~b}$ & $2,39 \mathrm{c}$ \\
\hline 4,5 & $4,64 \mathrm{AB}$ a & $4,61 \mathrm{~A} \mathrm{a}$ & $2,57 \mathrm{bc}$ \\
\hline 5,5 & $5,51 \mathrm{~A} \mathrm{a}$ & $5,17 \mathrm{~A} \mathrm{a}$ & $3,08 \mathrm{abc}$ \\
\hline 6,5 & $4,24 \mathrm{~B} \mathrm{a}$ & $4,46 \mathrm{~A} \mathrm{a}$ & $3,48 \mathrm{ab}$ \\
\hline 7,5 & $3,97 \mathrm{~B} \mathrm{a}$ & $4,06 \mathrm{~A} \mathrm{a}$ & $3,21 \mathrm{a}$ \\
\hline \multicolumn{4}{|l|}{ Inoculação } \\
\hline com & & & $2,90 \mathrm{a}$ \\
\hline sem & & & $2,99 \mathrm{a}$ \\
\hline $\mathrm{CV} \%$ & & 14,63 & 20,04 \\
\hline \multicolumn{4}{|c|}{ Produção de tubérculos (g) com S. scabiei } \\
\hline & & Inverno & Verão \\
\hline pH do substrato & CI & SI & \multirow{3}{*}{$2,37 \mathrm{~b}$} \\
\hline 4 & $4,46 \mathrm{AB}$ a & $2,88 \mathrm{C} \mathrm{b}$ & \\
\hline 4,5 & $5,22 \mathrm{AB}$ a & $4,61 \mathrm{AB}$ a & \\
\hline 5,5 & $5,43 \mathrm{~A} \mathrm{a}$ & $5,17 \mathrm{~A} \mathrm{a}$ & $2,71 \mathrm{~b}$ \\
\hline 6,5 & $4,83 \mathrm{ABC}$ a & $4,46 \mathrm{AB}$ a & $3,68 \mathrm{a}$ \\
\hline 7,5 & $3,93 \mathrm{C} \mathrm{a}$ & $4,06 \mathrm{~B} \mathrm{a}$ & $3,61 \mathrm{a}$ \\
\hline \multicolumn{4}{|l|}{ Inoculação } \\
\hline Com & & & $3,07 \mathrm{a}$ \\
\hline Sem & & & $3,11 \mathrm{a}$ \\
\hline $\mathrm{CV} \%$ & & 11,05 & 19,25 \\
\hline \multicolumn{4}{|c|}{ Produção de tubérculos (g) } \\
\hline & Stre & ces sp. IBSBF 2959 & S. caviscabies \\
\hline \multicolumn{4}{|l|}{ pH do substrato } \\
\hline 4 & & $3,23 \mathrm{~b}$ & $3,23 \mathrm{~b}$ \\
\hline 4,5 & & $4,76 \mathrm{a}$ & $5,00 \mathrm{a}$ \\
\hline 5,5 & & $5,01 \mathrm{a}$ & $4,93 \mathrm{a}$ \\
\hline 6,5 & & $4,42 \mathrm{a}$ & $4,78 \mathrm{a}$ \\
\hline 7,5 & & $4,28 \mathrm{a}$ & $4,61 \mathrm{a}$ \\
\hline \multicolumn{4}{|l|}{ Inoculação } \\
\hline Com & & $4,46 \mathrm{a}$ & $4,81 \mathrm{a}$ \\
\hline Sem & & $4,21 \mathrm{a}$ & $4,21 \mathrm{~b}$ \\
\hline $\mathrm{CV} \%$ & & 13,74 & 12,49 \\
\hline
\end{tabular}

*Médias seguidas da mesma letra maiúscula na coluna e minúscula na linha não diferem entre si pelo teste de Tukey (P<0,05). (CI) Com inoculação; (SI) Sem inoculação. 
Nos ensaios realizados no verão para a espécie de S. scabiei, os substratos com pH 4,0 e 5,5 apresentaram a menor média de produtividade diferenciando-se estatisticamente dos substratos com pH 6,5 e 7,5.

Com relação à produtividade nos ensaios com as espécies de Streptomyces sp. IBSBF 2959 e S. caviscabies, as menores médias para os pesos dos tubérculos foram verificadas nos substratos com $\mathrm{pH} 4,0$, diferenciando-se estatisticamente dos pesos atingidos em outros valores de $\mathrm{pH}$.

A batata é considerada uma planta que apresenta boa tolerância a acidez do solo (DAY; LUDEKE, 1993). Entretanto, de uma forma geral, no presente estudo o substrato com $\mathrm{pH}$ 4,0 apresentou uma menor média de produtividade em praticamente todos os testes realizados. A produção de tubérculos foi menor em aproximadamente $27 \%$ quando comparado aos outros $\mathrm{pH}$. Assim ficou demonstrado que o nível de $\mathrm{pH}$ pode ser um fator limitante na produção da batata. A acidez do solo tem como características uma menor disponibilização de nutrientes, uma maior concentração de $\mathrm{Al}$ e Mn que podem reduzir a produtividade de tubérculos (TABALDI et al., 2007).

\subsection{Avaliação in vivo (casa de vegetação) da incidência e severidade da sarna da batata com diferentes regimes de irrigação do substrato inoculados com Streptomyces spp.}

Nos experimentos de avaliação dos três regimes de irrigação, as plantas apresentaram homogeneidade de crescimento até os 45 dias de plantio, realizando-se a irrigação $3 \mathrm{X}$ semana. A partir deste período onde a prática da irrigação foi efetuada de acordo com cada regime, as plantas começaram a se diferenciar quanto ao seu crescimento. Nos vasos onde a irrigação foi escassa, as plantas começaram a sofrer murchamento nos dias mais quentes, e clorose, sendo que a senescência foi antecipada. Nos tratamentos com alta irrigação, foi observada morte precoce das plantas em algumas parcelas.

\subsubsection{Incidência e severidade da sarna da batata}

As análises de variância em diferentes regimes de irrigação do substrato inoculadas com as espécies de S. acidiscabieis, S. scabiei, Streptomyces sp. e S. europaescabiei mostraram diferenças significativas $(\mathrm{P}<0,05)$ (Tabelas $11,12,13$ e 14). 
Nos testes realizados com a espécie de S. acidiscabies, nos diferentes regimes de irrigação do substrato não foram observadas diferenças significativas entre os três tratamentos nas duas épocas estudadas com relação à incidência e severidade da doença. As diferenças observadas foram somente com relação à presença ou não do fitopatógeno, sendo que as maiores médias foram obtidas nos tratamentos com inoculação (Tabela 11).

Tabela 11. Valores das médias das notas da incidência e severidade da sarna da batata a partir de plantas cultivadas em substratos inoculados ou não com a linhagem de S. acidiscabies IBSBF $2110^{\mathrm{T}}$ sob diferentes regimes de irrigação.

\begin{tabular}{cc|c}
\hline \multicolumn{2}{c}{ Incidência da doença } \\
\hline \multicolumn{1}{c}{ Inverno } & Verão \\
\hline Regimes de irrigação & \\
1 X na semana & $1,47 \mathrm{a}$ & $1,33 \mathrm{a}$ \\
3 X na semana & $1,50 \mathrm{a}$ & $1,36 \mathrm{a}$ \\
Diariamente & $1,44 \mathrm{a}$ & $1,28 \mathrm{a}$ \\
Inoculação & & \\
Com & $2,44 \mathrm{a}$ & $2,14 \mathrm{a}$ \\
Sem & $0,50 \mathrm{~b}$ & $0,50 \mathrm{~b}$ \\
\hline CV \% & 8,05 & 16,69 \\
\hline & Severidade da doença & \\
\hline & Inverno & Verão \\
\hline Regimes de irrigação & $1,43 \mathrm{a}$ & $1,29 \mathrm{a}$ \\
1 X na semana & $1,45 \mathrm{a}$ & $1,39 \mathrm{a}$ \\
3 X na semana & $1,41 \mathrm{a}$ & $1,39 \mathrm{a}$ \\
Diariamente & & \\
Inoculação & $2,36 \mathrm{a}$ & $2,21 \mathrm{a}$ \\
Com & $0,50 \mathrm{~b}$ & $0,50 \mathrm{~b}$ \\
\hline Sem & 24,31 & 15,55 \\
\hline CV \% &
\end{tabular}

*Médias seguidas da mesma letra não diferem entre si pelo teste de Tukey $(\mathrm{P}<0,05)$.

Na condição deste estudo não foi verificada interferência dos regimes de irrigação na incidência e severidade da sarna. Esses dados diferem dos obtidos por Larkin e colaboradores (2011) que verificaram, em condições de campo, que os tratamentos onde não foram realizadas irrigações resultaram em níveis mais baixos de sarna da batata quando comparados aos tratamentos com irrigações. 
Tabela 12. Valores das médias das notas da incidência e severidade da sarna da batata a partir de plantas cultivadas em substratos inoculados ou não com a linhagem de S. scabiei IBSBF 2950 sob diferentes regimes de irrigação.

\begin{tabular}{|c|c|c|c|}
\hline \multicolumn{4}{|c|}{ Incidência da doença } \\
\hline \multicolumn{4}{|l|}{ Regimes de irrigação } \\
\hline $1 \mathrm{X}$ na semana & \multicolumn{3}{|c|}{$1,20 \mathrm{a}$} \\
\hline $3 \mathrm{X}$ na semana & \multicolumn{3}{|c|}{$1,35 \mathrm{a}$} \\
\hline Diariamente & \multicolumn{3}{|c|}{$1,30 \mathrm{a}$} \\
\hline \multicolumn{4}{|l|}{ Inoculação } \\
\hline Com & \multicolumn{3}{|c|}{$2,07 \mathrm{a}$} \\
\hline Sem & \multicolumn{3}{|c|}{$0,50 \mathrm{~b}$} \\
\hline $\mathrm{CV} \%$ & \multicolumn{3}{|c|}{11,81} \\
\hline \multicolumn{4}{|c|}{ Severidade da doença } \\
\hline Regimes de irrigação & CI & & SI \\
\hline $1 \mathrm{X}$ na semana & $1,91 \mathrm{~B} \mathrm{a}$ & & $0,50 \mathrm{~A} \mathrm{~b}$ \\
\hline $3 \mathrm{X}$ na semana & $2,34 \mathrm{~A} \mathrm{a}$ & & $0,50 \mathrm{~A} \mathrm{~b}$ \\
\hline Diariamente & $2,09 \mathrm{~B} \mathrm{a}$ & & $0,50 \mathrm{~A} \mathrm{~b}$ \\
\hline $\mathrm{CV} \%$ & & 9,53 & \\
\hline
\end{tabular}

\footnotetext{
*Médias seguidas da mesma letra maiúscula na coluna e minúscula na linha não diferem entre si pelo teste de Tukey (P<0,05). (CI) Com inoculação; (SI) Sem inoculação.
}

Com relação à incidência da doença nos testes realizados com a linhagem de $S$. scabiei, não foram verificadas diferenças significativas entre os três regimes de irrigação estudados. A diferença observada foi somente com relação aos tratamentos que foram inoculados ou não com o patógeno, sendo que as maiores médias foram obtidas pelos tratamentos com a presença da bactéria. Ainda, a maior média de severidade da doença foi registrada no regime de irrigação de três vezes na semana (tratamento considerado controle), diferenciando-se estatisticamente do regime de irrigação de uma vez na semana e diariamente (Tabela 12).

Dessa forma, os tratamentos que receberam mais água e os que receberam menor quantidade apresentaram as menores notas de severidade da doença. Esses dados foram contrastados com os obtidos por Wilson, Pemberton e Ransom (2001). Esses autores utilizaram a mesma espécie bacteriana nos experimentos e concluíram que o tratamento que recebeu menor quantidade de água apresentou maior incidência da doença.

Para os testes realizados com a linhagem de Streptomyces sp. IBSBF 2959 (Tabela 13) não foram verificadas diferenças significativas entre os tratamentos de regime de irrigação com relação à incidência e severidade da doença. Entretanto, cabe citar que os tratamentos 
que foram inoculados com a bactéria apresentaram resultado significativamente maior dos que não foram inoculados com o patógeno.

Tabela 13. Valores das médias das notas da incidência e severidade da sarna da batata a partir de plantas cultivadas em substratos inoculados ou não com a linhagem de Streptomyces sp. IBSBF 2959 sob diferentes regimes de irrigação.

\begin{tabular}{cc}
\hline \multicolumn{1}{c}{ Incidência da doença } & \\
\hline Regimes de irrigação & $1,37 \mathrm{a}$ \\
1 X na semana & $1,15 \mathrm{a}$ \\
3 X na semana & $1,27 \mathrm{a}$ \\
Diariamente & \\
Inoculação & $2,03 \mathrm{a}$ \\
Com & $0,5 \mathrm{~b}$ \\
Sem & 18,12 \\
\hline CV \% & \\
Severidade da doença & $1,50 \mathrm{a}$ \\
\hline Regimes de irrigação & $1,37 \mathrm{a}$ \\
1 X na semana & $1,54 \mathrm{a}$ \\
3 X na semana & \\
Diariamente & $2,44 \mathrm{a}$ \\
Inoculação & $0,50 \mathrm{~b}$ \\
\hline Com & 26,47 \\
\hline Sem & \\
\hline CV \% &
\end{tabular}

*Médias seguidas da mesma letra não diferem entre si pelo teste de Tukey $(\mathrm{P}<0,05)$.

Os dados obtidos no presente estudo indicaram que a umidade não interferiu na incidência e severidade da doença. Uma explicação para tal fato pode ser a questão de ter sido utilizado substrato esterilizado nos experimentos. De acordo com dados da literatura, a umidade ajuda no desenvolvimento de microrganismos antagonistas, que se movimentam nas películas de água do solo, colonizando mais rapidamente as lenticelas dos tubérculos, competindo assim com a linhagem de Streptomyces pela colonização da superfície da batata (Lewis, 1971). Larkin e colaboradores (2011) deixam claro que a relação entre a umidade do solo e a doença sarna é mais complexa do que se possa imaginar.

Nos testes com a linhagem de S. europaescabiei, a maior incidência da doença foi observada onde a irrigação foi efetuada em dias alternados (três vezes na semana), considerando-se o tratamento controle. Verificou-se que este regime apresentou diferença significativa com relação aos outros tratamentos. Os tratamentos que foram mantidos com 
maior e menor umidade apresentaram queda na incidência da doença, e não mostraram diferenças significativas com os tratamentos efetuados sem adição da bactéria (Tabela 14). Com relação à severidade da doença também pode se observar maiores médias no tratamento onde a irrigação foi efetuada em dias alternados (3 vezes na semana). Johansen e colaboradores (2014) também realizaram o mesmo tipo de experimento também empregando uma linhagem de S. europaeiscabiei, por um período de três anos, e verificaram variação da incidência de sarna entre cada ano de plantio. Durante dois anos, o tratamento que foi mantido em solo seco (uma vez por semana) apresentou maior incidência da doença. No terceiro ano, o tratamento de irrigação considerada normal (controle, três vezes na semana) foi o que apresentou maior incidência da doença, corroborando os dados obtidos no presente estudo.

Tabela 14. Valores das médias das notas da incidência e severidade da sarna da batata a partir de plantas cultivadas em substratos inoculados ou não com a linhagem de S. europaeiscabiei IBSBF $2023^{\mathrm{T}}$ sob diferentes regimes de irrigação.

\begin{tabular}{|c|c|c|}
\hline \multicolumn{3}{|c|}{ Incidência da doença } \\
\hline Regimes de irrigação & CI & SI \\
\hline $1 \mathrm{X}$ na semana & $0,70 \mathrm{~B} \mathrm{a}$ & $0,50 \mathrm{~A} \mathrm{a}$ \\
\hline $3 \mathrm{X}$ na semana & $1,58 \mathrm{~A} \mathrm{a}$ & $0,50 \mathrm{~A} \mathrm{~b}$ \\
\hline Diariamente & $0,90 \mathrm{~B} \mathrm{a}$ & $0,50 \mathrm{~A} \mathrm{a}$ \\
\hline $\mathrm{CV} \%$ & \multicolumn{2}{|c|}{ CV \% } \\
\hline \multicolumn{3}{|c|}{ Severidade da doença } \\
\hline Regimes de irrigação & CI & SI \\
\hline $1 \mathrm{X}$ na semana & $0,70 \mathrm{~B} \mathrm{a}$ & $0,50 \mathrm{~A} \mathrm{a}$ \\
\hline $3 \mathrm{X}$ na semana & $1,89 \mathrm{~A} \mathrm{a}$ & $0,50 \mathrm{~A} \mathrm{~b}$ \\
\hline Diariamente & $0,98 \mathrm{~B} \mathrm{a}$ & $0,50 \mathrm{~A} \mathrm{a}$ \\
\hline
\end{tabular}

*Médias seguidas da mesma letra maiúscula na coluna e minúscula na linha não diferem entre si pelo teste de Tukey $(\mathbf{P}<0,05)$. (CI) Com inoculação; (SI) Sem inoculação.

\subsubsection{Produtividade de tubérculos}

Nos testes realizados no inverno com a espécie de $S$. acidiscabies, a menor produtividade foi obtida onde a irrigação foi realizada apenas uma vez na semana, com média de 2,86 g; diferenciando-se estatisticamente dos outros regimes de irrigação onde o nível de umidade do substrato foi maior.

No estudo realizado com S. europaeiscabiei, a menor média de produtividade também foi obtida onde a irrigação foi efetuada apenas uma vez na semana diferenciando-se 
estatisticamente do tratamento que recebeu irrigação diariamente e que apresentou a maior média de produtividade. A planta de batata apresenta uma baixa tolerância ao déficit hídrico, principalmente durante o estágio de estolonização e início de tuberização da batata. Essa baixa tolerância pode ser atribuída ao seu sistema radicular ser pouco ramificado e superficial, por apresentar sensível redução do transporte de fotoassimilados na planta e tendência ao fechamento estomático sob tais condições, acarretando perdas de produtividade (MAROUELLI; GUIMARÃES, 2006). Este relato corroborou os nossos dados, onde se verificou que no tratamento com irrigação escassa a produtividade foi menor.

Os dados de produtividade dos tubérculos de batata nos experimentos com as linhagens de $S$. acidiscabies realizados no verão e aqueles efetuados com as linhagens $S$. scabiei e Streptomyces sp. realizados no inverno, não diferiram significativamente com relação aos três regimes de irrigação. Além disso, a produtividade obtida nos ensaios com presença e ausência do patógeno não mostrou diferença significativa entre os diferentes tratamentos. 
Tabela 15. Valores das médias de produtividade dos tubérculos de batata em (gramas) em diferentes regimes de irrigação dos substratos com linhagens de Streptomyces spp.

\begin{tabular}{cc|c}
\hline \multicolumn{2}{c}{ Produção de tubérculos (g) com S. acidiscabies } \\
\hline \multicolumn{1}{c}{ Inverno } & Verão \\
\hline Regimes de irrigação & \\
1 X na semana & $2,86 \mathrm{~b}$ & $3,26 \mathrm{a}$ \\
3 X na semana & $3,68 \mathrm{a}$ & $3,61 \mathrm{a}$ \\
Diariamente & $3,59 \mathrm{a}$ & $3,38 \mathrm{a}$ \\
Inoculação & & \\
Com & $3,54 \mathrm{a}$ & $3,35 \mathrm{a}$ \\
Sem & $3,21 \mathrm{a}$ & $3,48 \mathrm{a}$ \\
\hline CV \% & 16,32 & 20,54 \\
\hline
\end{tabular}

\section{Regimes de irrigação}

$\begin{array}{cl}1 \text { X na semana } & 1,98 \mathrm{a} \\ 3 \mathrm{X} \text { na semana } & 2,64 \mathrm{a} \\ \text { Diariamente } & 2,22 \mathrm{a}\end{array}$

\section{Inoculação}

Com 2,13 a

\begin{tabular}{rr} 
Sem & 2,43 a \\
\hline CV \% & 30,17
\end{tabular}

Produção de tubérculos (g) com Streptomyces sp. IBSBF 2959

Regimes de irrigação

$1 \mathrm{X}$ na semana

$3,65 \mathrm{a}$

$3 \mathrm{X}$ na semana

$3,44 \mathrm{a}$

Diariamente

$3,40 \mathrm{a}$

Inoculação

Com

$3,51 \mathrm{a}$

Sem

3,48 a

$\mathrm{CV} \%$

18,86

Produção de tubérculos (g) com S. europaescabiei sp.

\section{Regimes de irrigação}

$1 \mathrm{X}$ na semana

$3 \mathrm{X}$ na semana

$3,91 \mathrm{ab}$

Diariamente

$4,55 \mathrm{a}$

Inoculação

\begin{tabular}{cc} 
Com & $3,75 \mathrm{a}$ \\
Sem & $4,21 \mathrm{a}$ \\
\hline CV \% & 18,45
\end{tabular}

*Médias seguidas da mesma letra não diferem entre si pelo teste de Tukey $(\mathrm{P}<0,05)$. 


\section{CONCLUSÕES}

- Nos tratamentos com substratos em pH 4,0 não foi verificada a presença de sintomas da doença nas diferentes espécies estudadas, demonstrando que esta prática pode vir a ser uma estratégia de manejo da sarna da batata, porém a baixa produtividade de tubérculos obtidos neste valor de $\mathrm{pH}$ torna-se um fator limitante para sua aplicabilidade no campo.

- Os tratamentos com substratos em $\mathrm{pH}$ 4,5 foram os que apresentaram as menores notas de incidência e severidade da doença sem que a produtividade fosse afetada, se mostrando uma estratégia promissora para o manejo da doença.

- A espécie S. acidiscabies foi a única a causar sintomas da doença em todos os valores de $\mathrm{pH}$ avaliados.

- As linhagens nacionais de Streptomyces scabiei (IBSBF 2950) e Streptomyces sp. (IBSBF 2959) apresentaram comportamento semelhante ao da linhagem de $S$. acidiscabies com relação à patogenicidade e alta agressividade.

- No presente estudo, o fator irrigação não interferiu na incidência e severidade da sarna da batata para quase todas as espécies testadas, com exceção de S. europaescabiei que apresentou as maiores incidências e severidades da doença onde a irrigação foi realizada três vezes na semana. 


\section{CONSIDERAÇÕES FINAIS}

As conclusões deste trabalho, com relação aos ensaios de $\mathrm{pH}$, foram exclusivamente obtidas de experimentos realizados em nível de casa de vegetação, considerados como testes preliminares importantes e com resultados promissores para o emprego de tal prática em nível de campo. A correção de $\mathrm{pH}$ do solo é muito comum nas regiões produtoras de batata. Entretanto, os valores são acertados para pH 5,5 a 6,5. No presente estudo, verificamos que nestes valores de $\mathrm{pH}$ foram observadas as maiores notas de incidência e severidade da doença, ou seja, de acordo com nossos dados a prática usual de aumento de $\mathrm{pH}$ do solo, visando a melhor disponibilização de nutrientes, poderia vir a agravar ainda mais o problema da doença no campo. Neste sentido, outros estudos quanto à fertilidade do solo se fazem necessários para um melhor entendimento da relação $\mathrm{pH} /$ nutrientes/sarna da batata.

Os resultados deste trabalho mostraram que as notas de incidência da doença aumentaram concomitantemente ao acréscimo dos valores de $\mathrm{pH}$, indicando, mais uma vez, que esta doença é extremamente complexa e que dificilmente um único fator de prática cultural venha a ser eficiente no manejo da doença. Entendemos que diferentes estratégias combinadas devam ser aplicadas para se atingir tal objetivo. 


\section{REFERÊNCIAS BIBLIOGRÁFICAS}

ACUÑA, I. A.; STROBEL, G. A.; JACOBSEN, B. J.; CORSINI, D. L. Glucosylation as a mechanism of resistance to thaxtomin A in potatoes. Plant Science, v. 161, n. 1, p. 77- 88, 2001.

ADAMS, M. J.; LAPWOOD, D. H. Studies on the lenticels development, surface microflora and infection by common scab (S. scabiei) of potato tubers growing in wet and dry soils. Annals of Apllied Biology, v. 90, p. 335-343, 1978.

AGRIANUAL 2018. São Paulo: FNP Consultoria e Comércio, 2018.

AGRIOS, G. N. Plant pathology, 4th ed. Academic Press, San Diego, 1997.

ANDERSON , A. S.; WELLINGTON , E. M. The taxonomy of Streptomyces and related genera. International Journal of Systematic and Evolutionary Microbiology, v.51, p. 797 $814,2001$.

BABCOCK, M. J; ECKWALL, E. C.; SCHOTTEL, J. L. Production and regulation of potatoscab-inducing phytotoxins by Streptomyces scabiei. Journal of General Microbiology, v. 139 , p. 1579-1586, 1993.

BERIAM, L. O. S.; ALMEIDA, I. M. G. Doenças Bacterianas da batata. In: SALAS, F. J. S.; TÖFOLI, J.G.(Eds.). Cultura da batata: pragas e doenças. São Paulo: Instituto Biológico, 2016. p. 127-151, Cap 6.

BETTIOL, W.; GHINI, R.; MARIANO, R.R.; MICHEREFF, S.J.; MATTOS, L.P;, ALVARADO, I.C.; PINTO, Z.V. Supressividade a fitopatógenos habitantes do solo, In: BETTIOL, W.; MORANDI, M. (Eds.), Biocontrole de Doenças de Plantas: Uso e Perspectivas. EMBRAPA Meio Ambiente, Jaguariúna, SP, pp. 187-208, 2009.

BOUCHEK-MECHICHE, K.; GARDAN, L.; NORMAND, P.; JOUAN, B. DNA relatedness among strains of Streptomyces pathogenic to potato in France: description of three new species, S. europaeiscabiei sp. nov. and S. stelliscabiei sp. nov. associated with common scab, and $S$. reticuliscabiei sp. nov. associated with netted scab. International Journal of Systematic and Evolutionary Microbiology, v. 50, p. 91-99, 2000.

BRADSHAW, J. E.; BRYAN, G. J.; RAMSEY, G. Genetic resources (including wild and cultivated Solanum species) and progress in their utilization in potato breeding. Potato Research, Wageningen, v. 49, n. 1, p. 49-65, 2006.

CAMPARONI, R. Caracterização da diversidade genética de linhagens de Streptomyces scabiei e avaliação do potencial antagônico de micro-organismos no controle da à sarna da batata. Dissertação (Mestrado). Instituto Biológico, São Pulo, 2015. 65p.

CIP. Variedade de papa nativa de Huncavelica - Perú. Centro Internacional de la Papa. FEDECH, Federación Departamental de Comunidades Campesianas. Metrocolor: catálago. Lima, Perú: 208 p. 2006. 
CORREAA, D. B. A. Caracterização morfológica, patogênica e molecular de linhagens de Streptomyces associadas à sarna da batata de diferentes regiões produtoras do Brasil. Dissertação (Mestrado em Genética e Biologia Molecular). Universidade Estadual de Campinas, Campinas. 2011. 169p. Disponível em: http://www.bibliotecadigital.unicamp.br/document/?code=000788896.

DAY, A. D.; LUDEKE, K. L. Plant nutrients in desert environments, potassium as a plant nutrient. Springer Berlin Heidelberg, p 49-51, 1993.

DEES, M. W.; SLETTEN, A.; HERMANSEN, A. Isolation and characterization of Streptomyces species from potato common scab lesions in Norway. Plant Pathology, v. 62, p. 217-225, 2013.

DEES, M. W.; WANNER, L. A. In search of better management of potato common scab. Potato Research, v. 55, p. 249-268, 2012.

DIAS, J. ${ }^{\text {a }}$ C. S. de; IAMAUTI, M. T. Doenças da Batateira In: KIMATI, H.; AMORIM, L.; BERGAMIN FILHO, A.; CAMARGO, L. E. A.; REZENDE, J. A. M. (Eds.). Manual de Fitopatologia. 3. ed. São Paulo: Agronômica Ceres, 1997. v. 2. 706p. Cap 14

DIETZ, A. Structure and taxonomy of Streptomyces. In: QUEENER, S.W.; DAY, L.E. (Eds.) Antibiotic Producing Streptomyces. London: Academic Press. 1986. Cap 1

DOUMBOU, C. L.; SAlOVE, M. K. H.; CRAWFORD, D. L.; BEAUliEU, C. Actinomycetes, promising tools to control plant diseases and to promote plant growth. Phytoprotection, v. 82, n. 3, p. 85-102, 2001.

EMATER/RS. 2008. Batata inglesa: Histórico, conservação, dicas culinárias, aptidões e receitas. São Lourenço do Sul. Folder.

EUZÉBY, J. P. LPSN (List of prokaryotic names with standing in nomenclature internet) Ultima atualização: Novembro, 2018. Disponível em: http://www.bacterio.net/. Acesso: 24 de Março de 2019.

EVANGELISTA-MARTINEZ, Z. Isolation and characterization of soil Streptomyces species as potential biological control agents against fungal plant pathogens. World Journal of Microbiology and Biotechnology, v. 30, n. 5, p. 1639- 1647, 2014.

FAO (Food and Agriculture Organization of the United Nations). Strengthening potato value chains: technical and policy options for developing countries, 2010. Disponível em: http://www.fao.org/docrep/013/i1710e/i1710e.pdf. Acesso: 02 de Julho de 2018

FAO (Food and Agriculture Organization of the United Nations). Why potato?, 2008. Disponível em: http://www.fao.org/potato-2008/en/aboutiyp/index.html. Acesso em: 02 de Julho de 2018.

FAO (Food and Agriculture Organization). Statistical Pocketbook World Food and Agriculture Organization of the United Nations, Rome, 2015. Disponível: http://www.fao.org/3/a-i4691e.pdf. Acesso: 03 de Julho de 2018 
FAUCHER, E.; OTRYSCO, B.; PARADIS, E.; HODGE, N. C.; STALL, R. E.; BEAULIEU, C. Characterization of Streptomyces causing russet scab in Quebec. Plant Disease, v. 77, p. 1217-1220, 1993.

FERNANDES, A. M.; SORATTO, R. P. Nutrição mineral, calagem e adubação da batateira. Botucatu: FEPAF; Itapetininga: ABBA, 2012. 121 p.

FIERS, M.; EDEL-HERMANN, V.; CHATOT, C.; HINGRAT, Y. L.; LABOUVETTE, C.; STEINBERG, C. Potato soil-borne diseases. A riview. Agronomy for Sustainable Development, v.32, p. 93-132, 2012.

FONTES, P. C. R. Preparo do solo, nutrição mineral e adubação da batateira. Viçosa, MG: Ed. UFV, 1997. 42 p.

FORTES, G.R.L.; PEREIRA, J.E.S. Classificação e descrição botânica. In: PEREIRA, A.S.; DANIELS, J. (eds.). O cultivo da batata na região sul do Brasil. Brasília: Embrapa Informação Tecnológica, 2003. p.53-143.

GODOY, R. C.B. de A oferta de batata no Brasil. BatataShow, no 3. Ano 1, 2001.

HAN, J.S; CHENG, J.H.; YOON,T.M.; SONG, J.; RAJKARNIKAR, A.; KIM, W.G.; YOO, I.D.; YANG, Y.Y. Biological control agent of common scab disease by antagonistic strain Bacillus sp. Sunhua. Journal of Applied Microbiology. Vol. 99, 213-221, 2005.

HAYASHI P., L. O. S.; SALAS, F. J. S. A história da batata. In: SALAS, F. J. S.; TÖFOLI, J.G.(Eds.). Cultura da batata: pragas e doenças. São Paulo: Instituto Biológico, 2017. Cap 1, p. 04-09.

HILL, J.; LAZAROVITS, G. A mail survey of growers to estimate potato common scab prevalence and economic loss in Canada. Canadian Journal of Plant Pathology, v. 27, p. 46-52, 2005.

HILTUNEN, L.H.; WECKMAN, A.; YLHÄINEN, A.; RITA, H.; RICHTER, E.; VALKONEN, J.P.T. Responses of potato cultivars to the common scab pathogens, Streptomyces scabiei and S. turgidiscabies. Annals of Applied Biology, Warwick, v.146, p.395-403, 2005.

HILTUNEN L. H.; ALANEN M, LAAKSO I, KANGAS A, VIRTANEN E, VALKONEN, J. P. T. Elimination of common scab sensitive progeny from a potato breeding population using thaxtomin A as a selective agent. Plant Pathology, v. 60, n. 3, p. 426-435, 2011.

HÖPER, H.; ALABOUVETTE, C. Importance of physical and chemical soil properties in the suppressiveness of soils to plant diseases. European Journal of Soil Biology. v.32, p. 41-58, 1996.

HOSNY, M.; ABO-ELYOUSR, K. A. M.; ASRAN, M. R.; SAEAD, F. A. Chemical control of potato common scab disease under field conditions. Archives of Phytopathology and Plant Protection, 2014. 
IBGE (Instituto Brasileiro de Geografia e Estatística). Indicadores IBGE - Estatística da Produção Agrícola/Maio 2018. Fundação Instituto Brasileiro de Geografia e Estatística, 2018.

Disponível

em:

https://biblioteca.ibge.gov.br/index.php/bibliotecacatalogo?viewdetalhes\&id=72415 Acesso em: 03 de Julho de 2018.

JADOSKI, S. M.; MAGGI, A. S. L.; BRUNETTA, L.; WAZNE, R. Sucessão de culturas na fitossanidade e produtividade da cultura da batata (Solanum tuberosum L.). Pesquisa Aplicada \& Agrotecnologia, v. 2, n. 1, p. 161-166, 2009

JAMES, W. C. An illustrated series of assessment keys for plant diseases, their preparation and usage. Canadian Plant Disease Survey, v. 51, n. 2, p. 61, 1971.

JOHANSEN TJ, DEES MW, HERMANSEN A. High soil moisture reduces common scab caused by Streptomyces turgidiscabies and Streptomyces europaeiscabiei in potato. Acta Agriculturae Scandinavica, Section B-soil \& Plant Sci. v.65, p.193-198, 2014.

LACEY, M.; WILSON, C. Relationship of common scab incidence of potatoes grown in Tasmanian ferrosol soils with $\mathrm{pH}$, exchangeable cations and other chemical properties of those soils. Journal of Phytopathology, v. 149, n. 11-12, p. 679-683, 2001.

LAMBERT D. H.; POWELSON M. L.; STEVENSON W. R. Nutritional interactions influencing diseases of potato. Am Journal Potato Res, Orono, v. 82, p. 309-319, 2005.

LAMBERT, D. H.; LORIA, R. Streptomyces acidiscabies sp. nov. International Journal of Systematic Bacteriology, v. 39, p. 393-396, 1989.

LAMBERT, D. H.; LORIA, R. Streptomyces scabiei sp. nov., nom. rev. International Journal of Systematic Bacteriology, v. 39, p. 387-392, 1989.

LARKIN, R. P.; HONEYCUTT, C. W.; GRIFFIN, T. S.; OLANYA, O. M.; HALLORAN, J. M.; HE, Z. Effects of different potato cropping system approaches and water management on soilborne diseases and soil microbial communities. Phytopathology, v. 101, p. 58-67, 2011.

LEBUDE, A.V.; BILDERBACK, T.E. 2009. The pour-through extraction procedure: A nutrient management tool for nursery crops. North Carolina Cooperative Extension. AG717-W. 8 pp.

LEWIS, B. G. Effects of water potential on the infection of potato tubers by Streptomyces scabies in soils. Annals of Applied Biology, v. 66, p. 83-88, 1971.

LORIA, R. Diseases caused by bacteria. Compendium of potato diseases. Minnesota: APS; St Paul, 2001.

LOPES, C. A.; DUVAL, A. M. Q. Epidemiologia e controle das bacterioses das hortaliças. In: ZAMBOLIM, L.; LOPES, C. A.; PICANÇO, M. C.; COSTA, H.(Eds.). Manejo Integrado de Doenças e Pragas: Hortaliças. Viçosa: Editora UFV, 2007. 502p. Cap. 4.

LOPES, C. A.; ZAMBOLIM, L. Medidas integradas de controle das doenças bacterianas da batata. Viçosa: UFV; DFP, 2007. 20p. 
LORIA, R.; BUKHALID, R. A.; FRY, B. A.; KING, R. R. Plant pathogenicity in the Genus Streptomyces. Plant Disease, v. 81, n. 8, p. 836-846, 1997.

LORIA, R.; CLARK, C. A.; BUKHALID, R. A.; FRY, B. A. Gram-positive bacteria: Streptomyces. American Phytopathological Society, v.91, p. 236-249, 2001.

LORIA, R.; KERS, J.; JOSHI, M. Evolution of plant pathogenicity in Streptomyces. Annual Review of Phytopathology, v. 44, p. 469-487, 2006.

MANZER, F. E.; STORCH, R. H.; SEWELL, G. H. Evidence for a relationship between certain soil arthropods and acid scab development. American Potato Journal, v. 61, p. 741746, 1984.

MAPA (Ministério da Agricultura, Pecuária e Abastecimento). Projeções do Agronegócio no Brasil 2009/10 a 2019/20. Disponível em: http://www.promoalgo.com.br/documentos/Projecoes\%20\%20Mapa\%20\%202009.10\%20a\% 202019.20.pdf. Acesso: 04 de Julho de 2018.

MAROUELLI, W. A.; GUIMARÃES, T. G. Irrigação na cultura da batata. Itapetininga: ABBA. 66p. 2006.

MCGREGOR, A. J.; WILSON, G. C. S. The influence of manganese on the development of potato scab. Plant and Soil, v. 25, p. 3-16, 1966.

MENG, Q; HANSON, L. E.; DOUCHES, D.; HAO, J. J. Managing scab disease of potato and radish caused by Streptomyces spp. using Bacillus amyloliquefaciens BAC03 and other biomaterials. Biological Control. Vol 67, 373-379, 2013.

MILLARD, W. A.; BURR, S. A study of twenty-four strains of Actinomyces and their relation to types of common scab of potato. Annals of Applied Biology, v. 13, p. 580-644, 1926.

MIYAJIMA, K.; TANAKA, F., TAKEUCHI, T.; KUNINAGA, S. Streptomyces turgidiscabies sp. nov. International Journal of Systematic Bacteriology, v. 48, p. 495-502, 1998.

MIZUNO, N.; YOSHIDA, H.; TADANO, T. Efficacy of Single Application Ammonium Sulfate in Suppressing Potato Common Scab. Soil Science and Plant Nutrition, v. 46, n. 3, p. 611-616, 2000.

MOHANRAJ, G.; SEKAR, T. Isolation and screening of actinomycetes from marine sediments for their potential to produce antimicrobials. International Journal LifeSc. Bt \& Pharm, v. 2(3), p. 115-126, 2013.

MUlder, A.; TURKEnsteEn, L. J. Potato diseases. Holland: Aardappel wereld magazine, 2005. 280p.

PARK, D. H.; KIM, J. S.; KWON, S. W.; WILSON, C.; YU, Y. M.; HUR, J. H.; LIM, C. K. Streptomyces luridiscabiei sp. nov., Streptomyces puniciscabiei sp. nov. and Streptomyces 
niveiscabiei sp. nov., which cause potato common scab disease in Korea. International Journal of Systematic and Evolutionary Microbiology, v. 53, p. 2049-2054, 2003.

PEREIRA, A. S. A evolução da batata no Brasil. In: Congresso Brasileiro de Olericultura, 51. Horticultura Brasileira 29. Viçosa, 2011.

PERSON, L. H.; MARTIN W. J. Soil rot of sweet potatoes in Louisiana. Phytopathology, v. 30, p. 913-926, 1940.

POWELSON, M. L.; JOHNSON, K. B.; ROWE, R. C. Management of diseases caused by soilborne pathogens. In: Potato Health Management. American Phytopathological Society Press, St. Paul Minnesota, USA, p.149-158, 1993.

RODRIGUES NETO, J.; DESTÉFANO, S. A. L.; SHIMOYAMA, N. Y. A sarna da batata causada por Streptomyces spp. Publicação Técnica ABBA, 31 p., 2008.

SALAS, F. J. S.; MULLER, C.; JOCYS T. Pragas da cultura de batata. In: SALAS, F. J. S.; TÖFOLI, J.G.(Eds.). Cultura da batata: pragas e doenças. São Paulo: Instituto Biológico, 2016. p. 1-36, Cap 1.

SALAS, F. J. S.; PEREIRA, L.S. Fitovírus em batata. In: SALAS, F. J. S.; TÖFOLI, J.G.(Eds.). Cultura da batata: pragas e doenças. São Paulo: Instituto Biológico, 2016. p. 95-126, Cap 5.

SCHEPERS, H.; WUSTMAN, R.; OOSTEWECHEL, R.; VERHEIJ, P. Oportunidades no sector da batata; Brasil uma análise das cadeinas de valor das sementes ao produto final. Holland Pionners in International Business. 2015

SHIMOYAMA, N. Produtor de batata aposta na diversificação de culturas para garantir o sucesso da atividade. In: Agrianual 2017. São Paulo: FNP Consultoria e Comércio. 2017 p. 161-162.

SHIMOYAMA, N. Y. A cadeia brasileira da batata - situação atual, 2014. Disponível em: http://consumoymercadodepapa.wordpress.com/2014/11/28/a-cadeia-brasileira-da-batatasituacao-atual. Acesso em: 13 de julho de 2018.

SILVA, E. F. DA.; JADOSKI, S. O. Caracterização histórica da cultura e prognóstico de evolução da produção de batata no Brasil. Pesquisa Aplicada \& Agrotecnologia, v.8, p.99 $106,2015$.

SLACK, S. A. A look at potato leafroll virus and potato virus Y: Past, present and future. Badger Common Tater, v. 43, p. 16-21, 1991.

SOUSA, D.M.G.; MIRANDA, L.N.; OLIVEIRA, S.A. Acidez do solo e sua correção. In: NOVAIS, R.F.; ALVAREZ V., V.H.; BARROS, N.F.; FONTES, R.L.F.; CANTARUTTI, R.B.; NEVES, J.C.L., eds. Fertilidade do solo. Viçosa, MG, Sociedade Brasileira de Ciência do Solo. p.205-274, 2007.

TABALDI, L. A.; NICOLOSO, F. T.; CASTRO, G. Y.; CARGNELUTTI, D.; GONÇALVES, J. F.; RAUBER, R.; SKREBSKY, E. C.; SCHETINGER, M. R. C.; 
MORSCH, V. M.; BISOGNIN, D. A. Physiological and oxidative stress responses of four potato clones to aluminum in nutrient solution. Brazilian Journal of Plant Physiology, Campinas, v.19, n. 3, p. 211-222, 2007.

TARKOWSKI, P.; VEREECKE, D. Threats and opportunities of plant pathogenic bacteria. Biotechnology Advances, v. 32, p. 215-229, 2014.

TOFOLI, J. G.; DOMINGUES, R. J.; ZANOTTA, S. Doenças fúngicas da batata. In: SALAS, F. J. S.; TÖFOLI, J.G.(Eds.). Cultura da batata: pragas e doenças. São Paulo: Instituto Biológico, 2016. p. 152-206, Cap 7.

WAKSMAN, S.A. The influence of soil reaction upon the growth of Actinomycetes causing potato scab. Rutgers College Studies, p. 61-79, 1921.

WANNER, L. A. A new strain of Streptomyces causing common scab in potato. Plant Disease, v. 91, p. 352-359, 2007.

WATERER, D. Impact of high soil $\mathrm{pH}$ on potato yields and grade losses to common scab. Department of Plant Sciences, University of Saskatchewan. Canadá, 2002.

WIECHEL, T. J.; CRUMP N. S. Soil nutrition and common scab disease of potato in Australia. World Congress of Soil Science, Soil Solution for a Changing World. Brisbane: Australia, 2010.

WILSON, C. R. A summary of common scab disease of potato research from Australia. Proceedings of the International Potato Scab Symposium 2004, Sapporo, Japan, Hokkaido University, 2004.

WILSON C. R.; PEMBERTON, B. M.; RANSOM, L. M. The effect of irrigation strategies during tuber initiation on marketable yield and development of common scab disease of potato in Russet Burbank in Tasmania. Potato Research, v. 44, p. 243-251, 2001.

WILSON, C. R.; RANSOM, L. M.; PEMBERTON, B. M. The relative importance of seedborne inoculum to common scab disease of potato and the efficacy of seed tuber and soil treatments for disease control. Journal of Phytopathology, 2008.

WILSON, C. R.; RANSON, L. M.; PEMBERTON, B. M. The relative importance of seedborne inoculums to common scab disease of potato and the efficacy of seed tuber and soil treatment for disease control. Journal of Phytopathology, v. 147, p. 13-18, 1999.

ZAMBOLIM, L.; CÁSSIA, R. M.; PICANÇO, M. C.; MANTOVANI, E. C.; QUEIROZ, M. E.; SOUZA, D. O.; BITTENCORT, L.; DUARTE, H. S. S.; PALOCCI NETO, O.; RIBEIRO, J. D. R.; PADUA, J. G. Produção Integrada de Batata. In: Ministério da Agricultura, Pecuária e Abastecimento. Secretária de Desenvolvimento Agropecuário e Cooperativismo. Produção integrada no Brasil: agropecuária sustentável alimentos seguros. Brasília: Mapa/ACS, 2009. Cap 11, p. 261-328. 